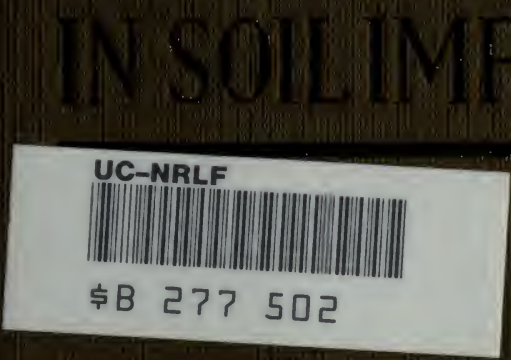




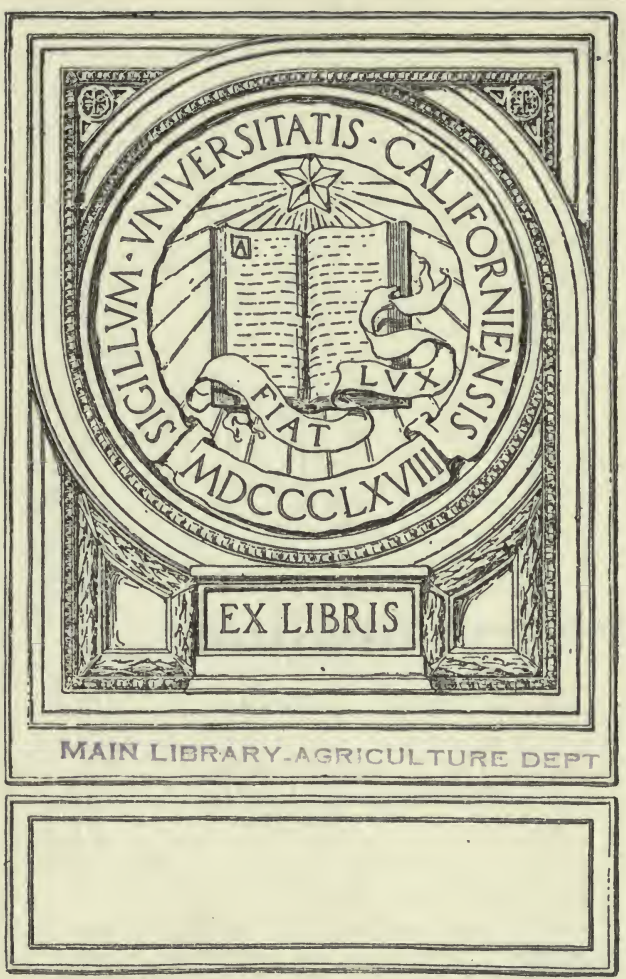







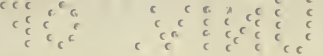

क्ष

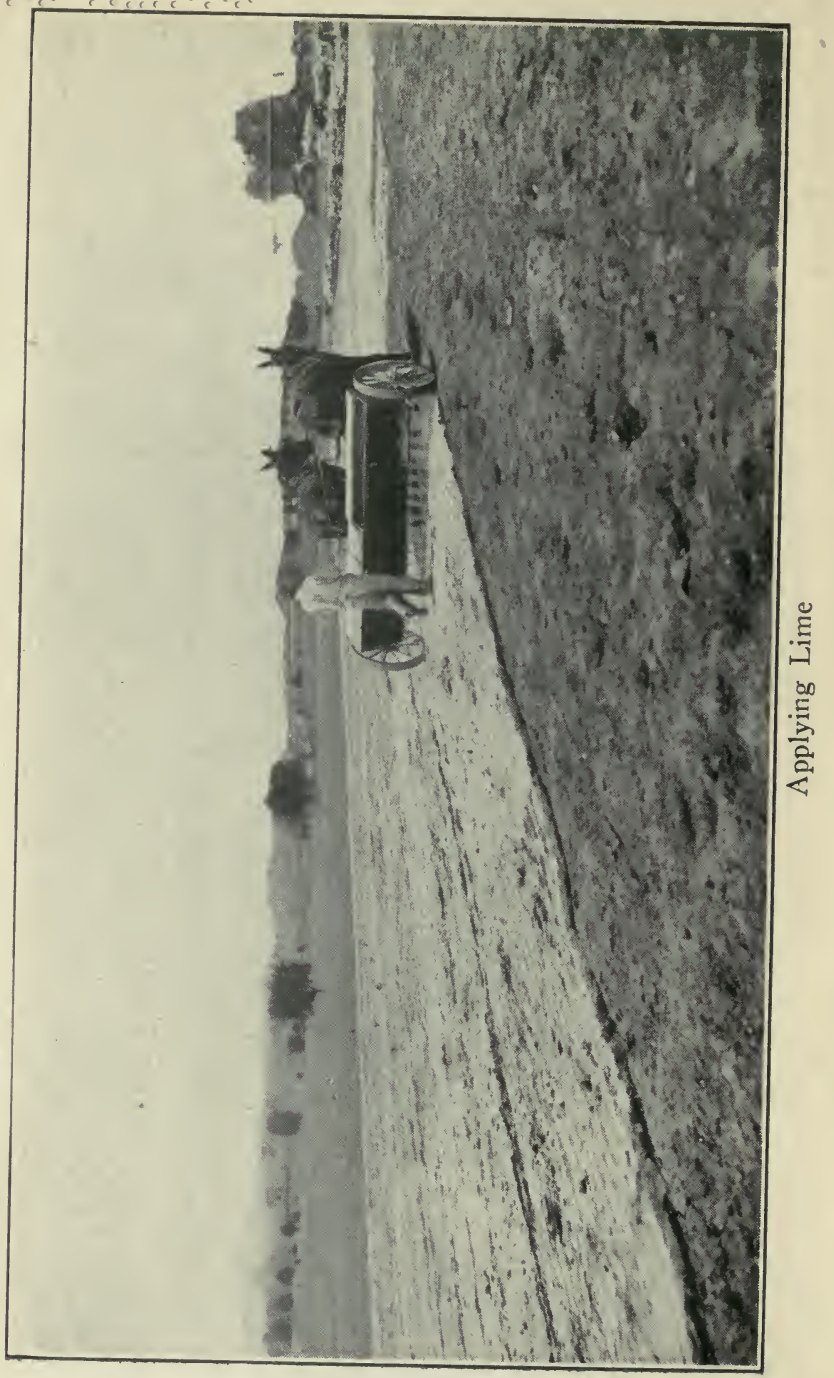




\title{
Right Use of Lime \\ In Soil Improvement
}

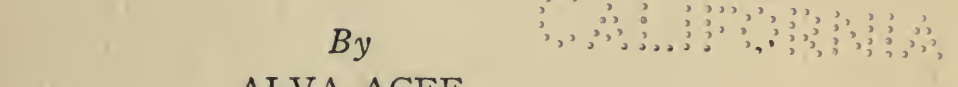

\author{
ALVA AGEE
}

Secretary New Jersey State Department of

Agriculture

Formerly director of agricultural extension in the Pennsylvania State College and New Jersey State

College of Agriculture.

\section{Illustrated}

NEW YORK

ORANGE JUDD COMPANY

LONDON

KEGAN PAUL, TRENCH, TRUBNER \& CO., LIMITED 


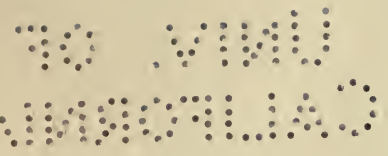

\section{$4 ! 4(821$}

Copyright 1919, by ORANGE JUDD COMPANY

All Rights Reserved

MAWN LIBRAF: .. RUNLIUFEE DEPT.

Printed in U. S. A. 


\section{CON'I'ENTS}

CHAPTER PAGE

I. INTRODUCTION

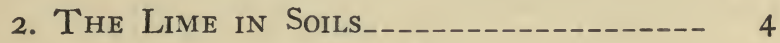

3. Sour SoILS _-

4. Evidences of Acidity_-_-_-_-_-_ I5

5. Tests FOR ACIDITY

6. Sources of LIME

7. Definitions _- 28

8. Ground Limestone _-_-_-_-_-_- 33

9. Storing Lime in the Soll_______ 38

io. Fresh Burned Lime__._. 44

I1. Burning LIME _- 49

12. Lime Hydrate _- 53

13. Other Forms of Lime___-_-_-_ 57

14. Magnesian Lime _... 64

15. What Shall One Buy? 68

16. Methods of Application_-_-_-_--- 78

17. Amount of Lime per Acre_-_._- 82

i8. Special Crop Demands______._. 86 
Digitized by the Internet Archive in 2007 with funding from Microsoft Corporation 


\section{ILLUSTRATIONS}

Applying Lime Frontispiece FACING PAGE

I. Clover and Timothy Unfertilized at the Pennsylvania Experiment Station Yielded 2,460

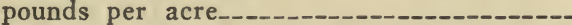

II. Clover and Timothy with Fertilizer alone at the Pennsylvania Experiment Station Yielded 3,900 pounds per acre

III. Clover and Timothy with Lime alone at the Pennsylvania Experiment Station Yielded 4,900 pounds per acre

IV. Clover and Timothy with Fertilizer and Lime at the Pennsylvania Experiment Station yielded 6,290 pounds per acre

V. Limed and Unlimed Ends of a Plot at the Ohio Experiment Station

VI. Effect of Finely Pulverized Limestone on Clover in a Soil having a Lime Requirement of 5,200 Pounds of Limestone per Acre, at the Pennsylvania Experiment Station

VII. Lime Favors Clover at the Ohio Experiment Station

VIII. Lime Affects Growth of Corn at the Ohio Experiment Station

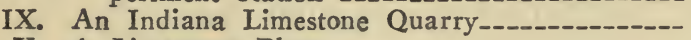

X. A Limestone Plant-_.-_-_(Courtesy of the Michigan Limestone Company.) XI. A Limestone Pulverizer for Farm Use-_-_-_--Columbus, Ohio.)

XII. A Lime Pulver in Operation

(Courtesy of the Jeffrey Manufacturing Company.)

XIII. Laying Foundation for a Lime Stack at the Pennsylvania Experiment Station.

XIV. A Stack nearly Completed at the Pennsylvania Experiment Station

XV. Effect of Excessive Use of Burned Lime without Manure at the Pennsylvania Experiment Station -- -

XVI. A Hydrated Lime Plant53

XVII. Filling the Lime Spreader at the Ohio Experiment Station -_-_-_-_-_-_- 78

XVIII. Lime Distributors
XIX. Remarkable Effect of Lime on Sweet Clover at are Supplied, Ohio Experiment Station...-. 



\section{CHAPTER I \\ INTRODUCTION}

7 HERE is much in the action of lime 1 in the soil that is not known, but all that we really need to know is simple and easily comprehended. The purpose of this little book is to set down the things that we need to know in order that we may make and keep our land friendly to plant life so far as lime is necessarily concerned with such an undertaking. Intelligent men like to reason matters out for themselves so far as practicable, taking the facts and testing them in their own thinking by some truth they have gained in their own experience and observation, and then their convictions stay by them and are acted upon. The whole story of the right use of lime on land is so simple and reasonable, when we stick only to the practical side, that we should easily escape the confusion of thought that seems to stand in the way of action. The experiment stations have been testing the value of lime applications to acid soils, and the government has been finding that the 
greater part of our farming lands is deficient in lime. Tens of thousands of farmers have confirmed the results of the stations that the application of lime is essential to profitable crop production on their farms. The confusion is due to some results of the misuse of lime before the needs of soils were understood, and to the variety of forms in which lime comes to us and the rather conflicting claims made for these various forms. It is unfortunate and unnecessary.

The soil is a great chemical laboratory, but exact knowledge of all its processes doubtless would enrich the farmer's vocabulary more than his pocketbook. We are concerned in knowing that lime's field of usefulness is broad in that it is an essential plant food and provides the active means of keeping the feeding ground of plants in sanitary condition. We want to know how it comes about that our soils are deficient in lime, and how we may determine the fact that they are deficient. We wish to know the relative values of the various forms of lime and how we may choose in the interest of our soil and our pocketbook. The time and method of 
application are important considerations to us. There are many details of knowledge, it is true, and yet all fit into a rational scheme that shows itself to be simple enough when the facts arrange themselves in an orderly way in our minds.

Lime cannot take the place of nitrogen, nor phosphorus, nor any other of the essential plant foods. It is not a substitute for any other essential factor in plant growth. It would be folly to try to depend upon lime as a sole source of soil fertility. On the other hand, we have learned very definitely within the last quarter of a century that it is foolish to depend upon commercial fertilizers and tillage and good seeds for full production of most crops from great areas of our farming country that have a marked lime deficiency. The obvious need of our soils is the rich organic matter that clover and grass sods could furnish, and their fundamental need is lime. Most farms cannot possibly make full returns to their owners until the land's hunger for lime has been met. The only question is that regarding the best way of meeting it. 


\section{CHAPTER II \\ THE LIME IN SOILS}

Limestone Land. Soil analyses are serviceable only within certain limits, and in the case of the normal soils that comprise the very great part of the entire humid region of the United States the practical man gives little heed to what special analyses might show him when deciding upon the purchase of a farm. He does know, however, that a limestone soil has great natural strength, and recovers from mistreatment more readily than land low in lime. It has staying powers, and is dependable, unless through natural processes the lime leaches out or loses availability. All limestone areas have gained reputation for themselves as producers of grain and grass.

Other Calcareous Soils. It is not only the limestone areas that stand high in esteem. There are types of soil with every varying percentage of lime down to clear sand or to peat', and some of the types are finely calcareous, containing such a high 
percentage of lime that nothing more could be desired.

The actual percentage is not the determining factor, a clay soil needing greater richness in this material than a loam, and a sandy soil giving a good account of itself with an even less total content of lime, but in its way the particular soil type must be well supplied by nature with lime if its trees and other vegetation bear evidences of its strength and good agricultural value.

Natural Deficiency. It is interesting to note the differences in evidences of prosperity that are associated with lime percentages. The areas that are able to produce the vegetation characteristic of calcareous soils are obviously the most prosperous. The decidedly lime-deficient sections, advertising their state by the kind of original timber, and later by unfriendliness to the clovers, do not attract buyers except through relatively low prices for farms. Such areas are extensive and have well marked boundaries in places.

It does not follow that every farm in such limestone valleys as the Shenandoah, Cumberland, and Lebanon, or in the great corn belt having a naturally calcareous soil, is 
prosperous, or that a multitude of owners of such lime-deficient areas as the belt in a portion of southern New York and northern Pennsylvania, or the sandstone and shale regions of many states, have not overmatched natural conditions with fine skill. We treat only of averages when saying that a "lime country" shows a prosperity in its farm buildings and general appearance that does not come naturally and easily to any lime-deficient territory. In the latter a man rows against the current, and if livestock farming is not employed to furnish manure, and if the manure is not supplemented by tillage and drainage to secure aeration, or if lime is not applied, the land reaches such a degree of acidity that it loses the power to yield any profit.

Nature's Short Supply. The total area of lime-deficient soil is large, comprising certainly much more than half of all the land east of the semi-arid belt of the United States. No small part of this area was not deficient at one time, as the nature of the original timber indicates, and it is well within the knowledge of practical men that land which once produced the walnut and ash and shellbark hickory can be brought 
back to productivity with reasonable ease after very hard usage. It has a good inheritance. It is a disconcerting fact in our American agriculture that, fertile as our country is as a whole, very great areas were so deficient in lime before they came under man's control that the chestnut, pine, and the oaks of mean growth were fully at home. The gradation from low lime content to high, and its relation to soil type, give us all sorts of mixtures of lime-loving and acid-resistant varieties of trees in original forests, but our agriculture is hampered by the high percentage of land for which nature made no great provision of lime, and on this land farming lags.

Effect of Irrational Farming. Interest in liming might well have been due to the amendment of all this soil, but the rational use of lime that has been the subject of much study in the last quarter of a century concerns chiefly great areas that probably could have been kept in alkaline condition and friendly to the clovers for a long time despite a short natural supply as compared with the content of our limestone lands. The success of individual farmers in areas now admittedly acid as a whole is con- 
vincing on this point. Nature tries constantly to cure the ills of her soil through the addition of vegetable matter. An excess of water or a deficiency is atoned for in a degree by the leaves and rotted wood of her forests. Aeration is kept possible. The lime in the product of the soil goes back to it. A system of farming that involves the application of manure, thorough tillage, drainage where needed, and the free use of sods in some way, has kept portions of these non-calcareous soils out of the distinctly acid class. Clover grows satisfactorily, grass sods are heavy, and there is no acute lime problem. Such farms are relatively few in the great stretches of land now classed as acid soil, and probably the most of the lime that is being applied goes only on ground that once was sufficiently alkaline to grow the clovers. The loss of organic matter through failure to use the best methods of farming is responsible for no small part of the widespread need of lime today. This subtracts nothing from the urgency of its use to restore a condition favoring clover and grass sods, but it does teach a lesson of the highest value. The day of destructive soil acidity can be re- 
tarded by good farming, but in the long run the inevitable losses of lime from most soils must be met by applications.

Limestone Soils. The old-time practice of making heavy applications of fresh burned lime to stiff limestone soils to make them friable, and to make their plant food available, led to disuse of all lime in some sections on account of the exhaustion that followed dependence upon these large amounts as a manure. Queerly enough, these original limestone soils have latterly been going into the acid class through loss of their distinctive elements, and they, too, have become dependent upon means for the correction of acidity. 


\section{CHAPTER III SOUR SOILS}

Loss of Lime. Nature made the value of land as a producer of food utterly dependent upon the activity of lime, and at the same time gave it some power to shirk its work. In a normal soil is a percentage of lime that came from the disintegration of rock of the region or was transported by action of water on a huge scale. Possibly rarely would it be in insufficient amount to keep a soil in a condition friendly to plant life, and to feed the plant, if it stayed where nature placed it and kept in form available for the needs it was intended to meet. There is land that always was notably deficient in this material, and there is land that was known in the early history of the world's agriculture to be "sour," but the troubles of our present day in the case of the farming country in the humid region of the United States is less due to any natural absolute shortage than to combination that destroys value and to escape by action of water. 


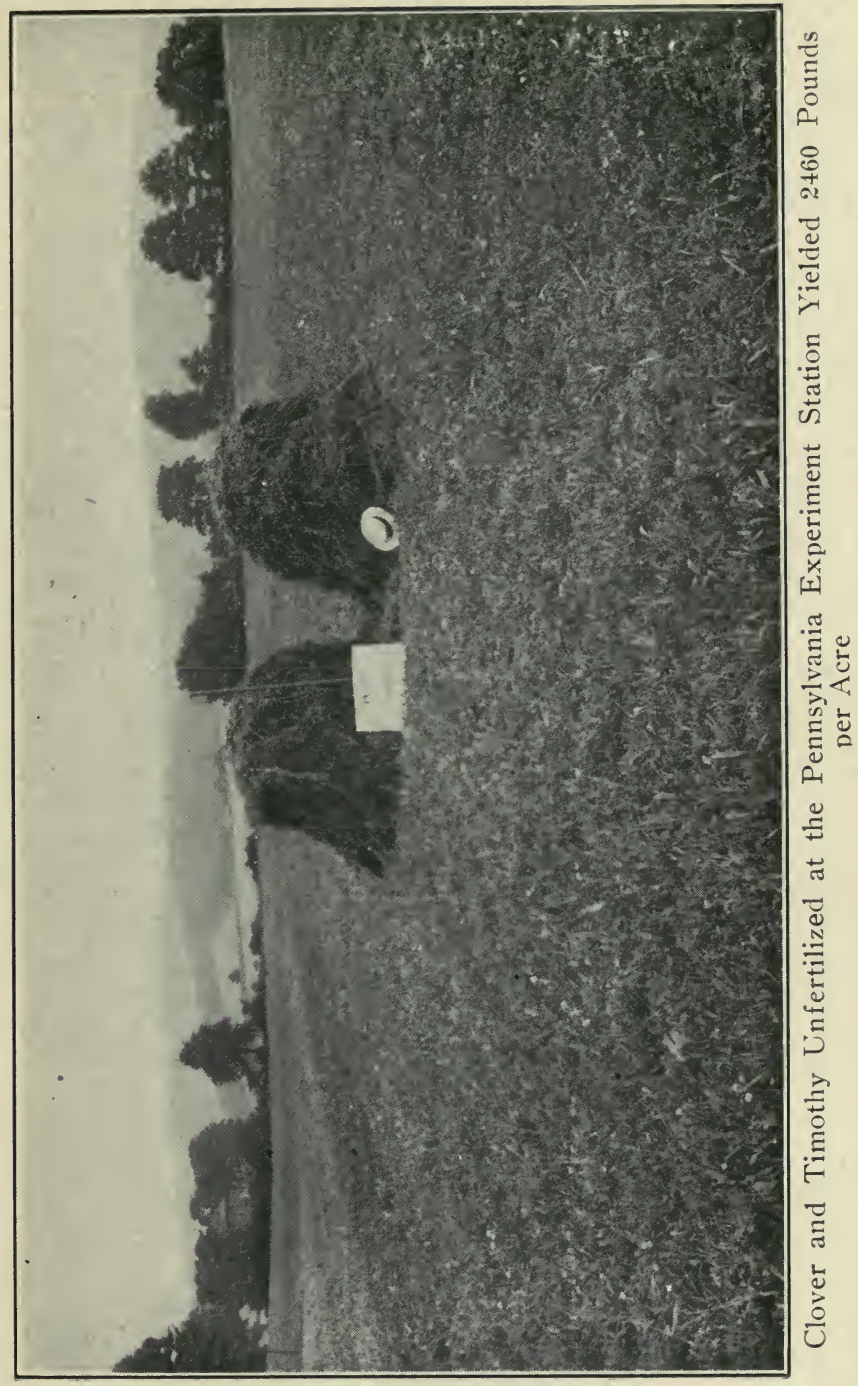




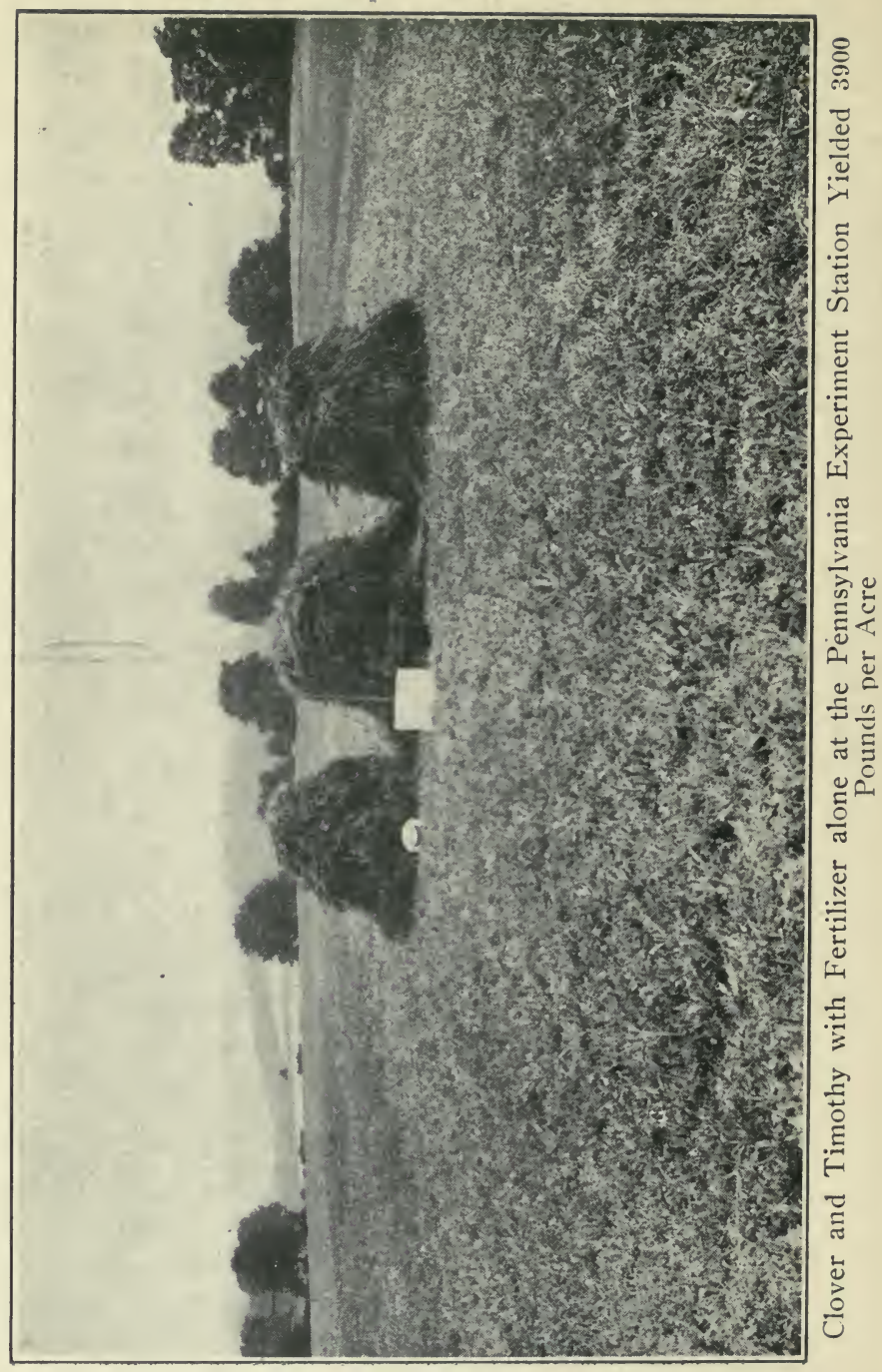


Prevalence of Acidity. The results of experiment station and farm tests are conclusive that the soils of the greater part of all the humid region of the United States show lime deficiency. Formerly, acidity was associated in our minds with wet, lowlying land, but within the last twenty years we have learned that it prevails in light seashore sands along the Atlantic shore, in clays, loams and shales stretching to the Appalachian system of mountains, on top of mountain ranges and across foothills to our central states, and through them in stretches to the semi-arid lands of the west. While not all this land has fallen into the limedeficient class, and the great part of some . states remains alkaline, the tendency toward acidity is continuous.

Crop production in great portions of the Mississippi valley is restricted by lack of lime in the soil, and some states to the eastward have one-half to nine-tenths of their acreage too low in lime for the best results. Calcareous soils have been losing their distinctive feature, and the immense areas of land naturally low in lime have remained hampered in ability to make full returns for labor, fertilizer and seed. It is this 
situation that brings the right use of lime on land to the front as a matter of fundamental importance to the farmer.

Causes of Soil Acidity. If any discussion of the causes of soil acidity would delay a decision to apply lime where needed, the time given to such discussion would be worse than wasted. It is much more important to be able to detect the presence of harmful acids and to neutralize them than it is to know why the soil should be in such plight that it could not supply the required lime and had become dependent upon its owner for assistance. On the other hand, some of us find it difficult to accept a fact without seeing a reason for it, and we may do well to consider several causes that may be at work to put a soil out of the alkaline class.

Leaching. One cause that appears obvious and easy of acceptance is leaching. In the case of one Pennsylvania farm, lying in a limestone valley, the lime had been washed out by action of water so freely that caverns formed under the surface, and a test showed a marked deficiency in the top soil. This land ceased to grow clover, and plantain and sorrel abounded. This case, 
which is not an isolated one, showed an unusually rapid loss, but we always expect to find the water from wells and springs in a limestone country strongly impregnated with lime. Drainage waters contain it. The draft by action of water is continuous, and in some types could easily account for sufficient loss to change the nature of the soil. We may place undue emphasis upon this factor, as other causes are at work, but leaching is a leading source of loss.

Chemical Compounds. A serious cause of lime exhaustion that is being studied by soil chemists is the presence of compounds in the soil that combine with the lime and rob it of ability to serve the soil when new acids form. The practical farmer accepts the statements of the chemists on this point, and probably would not have his interests served by any exact knowledge of the nature of these agents.

Decaying Vegetation. A cause of acid conditions that is widely known and accepted, and that may therefore stand out in our thinking with undue prominence, is connected with the decay of green vegetable matter in the soil. Many of us have seen fields rendered temporarily unproduc- 
tive by the plowing down of a mass of immature plants in midsummer. All organic matter, indeed, in its decay makes a draft upon the lime content of the soil in which it may be buried.

Removal in Crops. Lime is taken out of land by plants, and the loss is a considerable item, but our interest is in the form of lime that can correct soil acidity, and we know that compounds of lime that are worthless for this purpose may be the chief source of the lime in our crops. A determination of the lime in the ash of a crop does not give data of much practical value. 


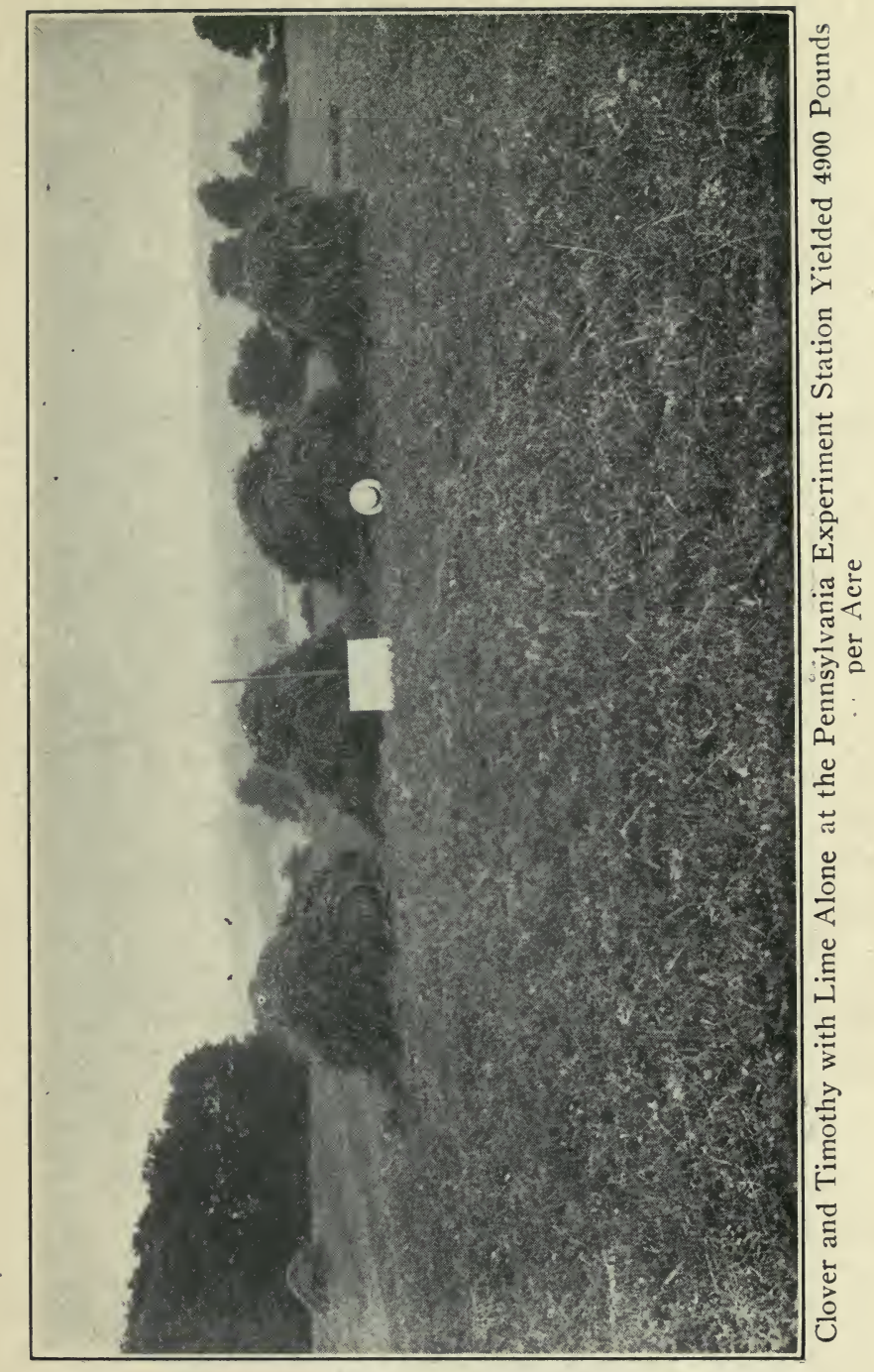




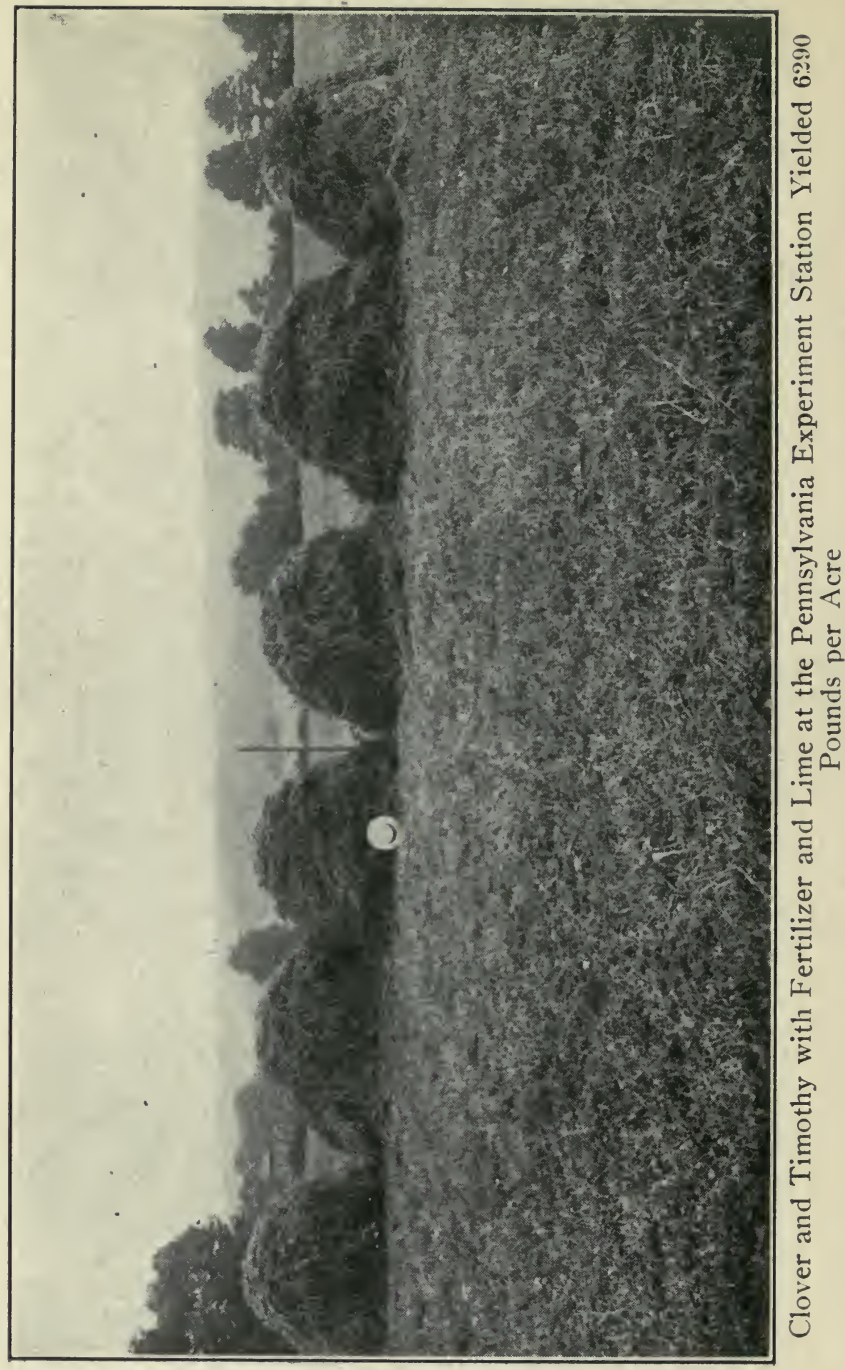




\section{CHAPTER IV \\ EVIDENCES OF ACIDITY}

Character of Vegetation. The character of the original forests is determined much by the lime-content, and the practical man, when buying a farm, rates its productive power by the kinds of timber it has produced. The black walnut, ash, shellbark hickory, black and white oak, sturdily grown, evidence a soil rich in lime, while the pines, small blackjack and post oaks, and the chestnut are at home in non-calcareous soils. The latter class of lands gains nothing in lime as time passes, and the timber continues to be a sure index, but in the former class the surface soil may have lost enough lime to limit crop production materially while the trees continue to find in the subsoil all that they need. It does not follow that the land has gone down in value to the naturally lime-deficient class, but its power to produce is impaired, and will remain so until there has been restoration of its original alkaline state.

Sorrel and Plantain. We determine 
quite surely the state of the soil by observance of the vegetation that roots in the surface soil and the immediate subsoil. Sorrel is a plant popularly associated with soil acidity, but this is not through any dislike for lime. It has been observed growing in the edge of a heap. Its presence suggests acidity because it can thrive in a sour soil that will not produce plants of value which on even terms could crowd the sorrel out. There is constant competition among plants for food and water and space, and some of our worst weeds are not strong competitors of clover and grass where soil conditions are not unfavorable to the latter.

Blue grass, the clovers and timothy give a good account of themselves in a contest with sorrel and plantain where lime is abundant. This does not mean that the seeds of these weeds may not be so numerous that an application of lime cannot cause the clover and grasses immediately to take the ground to the exclusion of other plants, but it is true that the crowding process will continue until the time comes in the crop rotation that these weeds cease to be feared, and clean sods can be made. It is the absence of lime that permits such weeds to maintain 


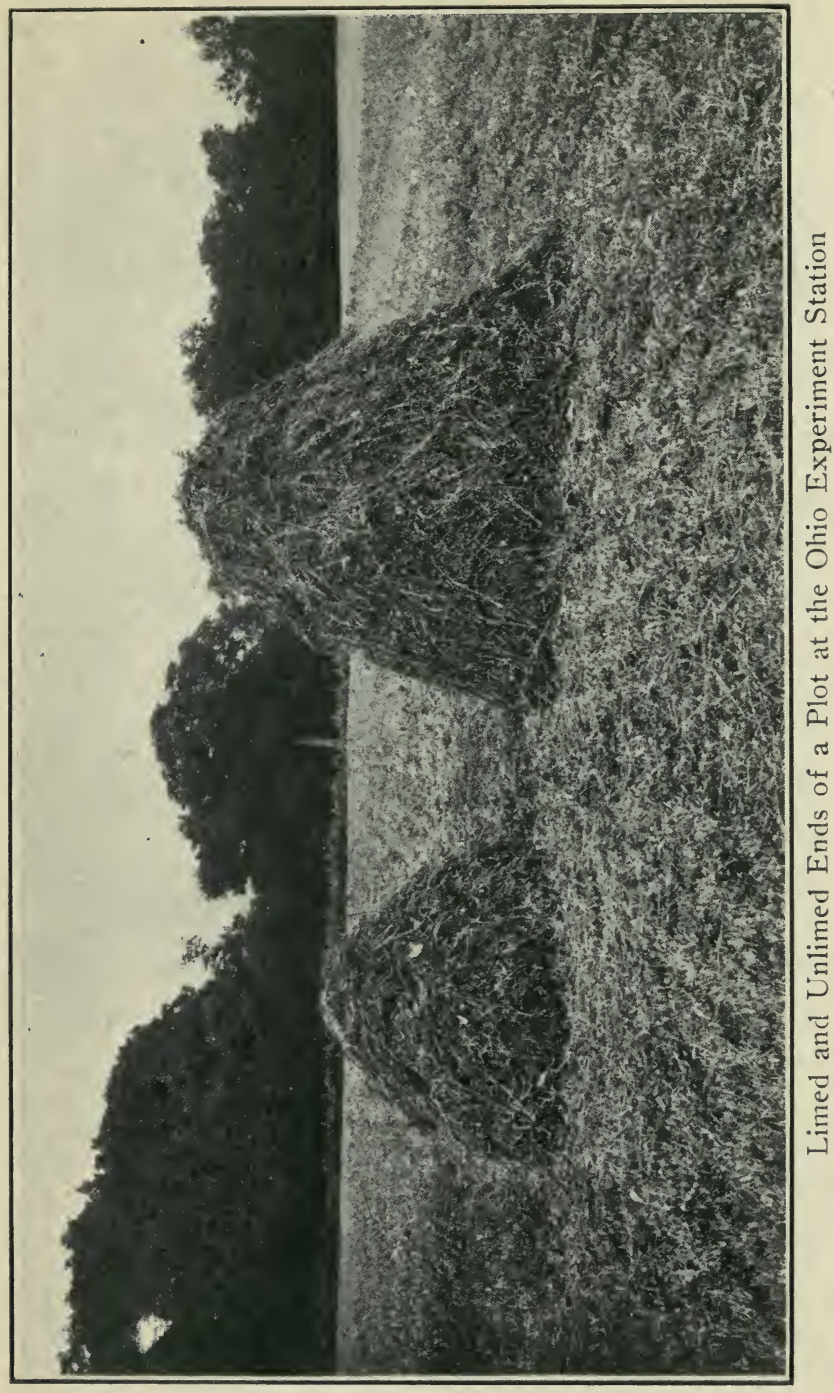




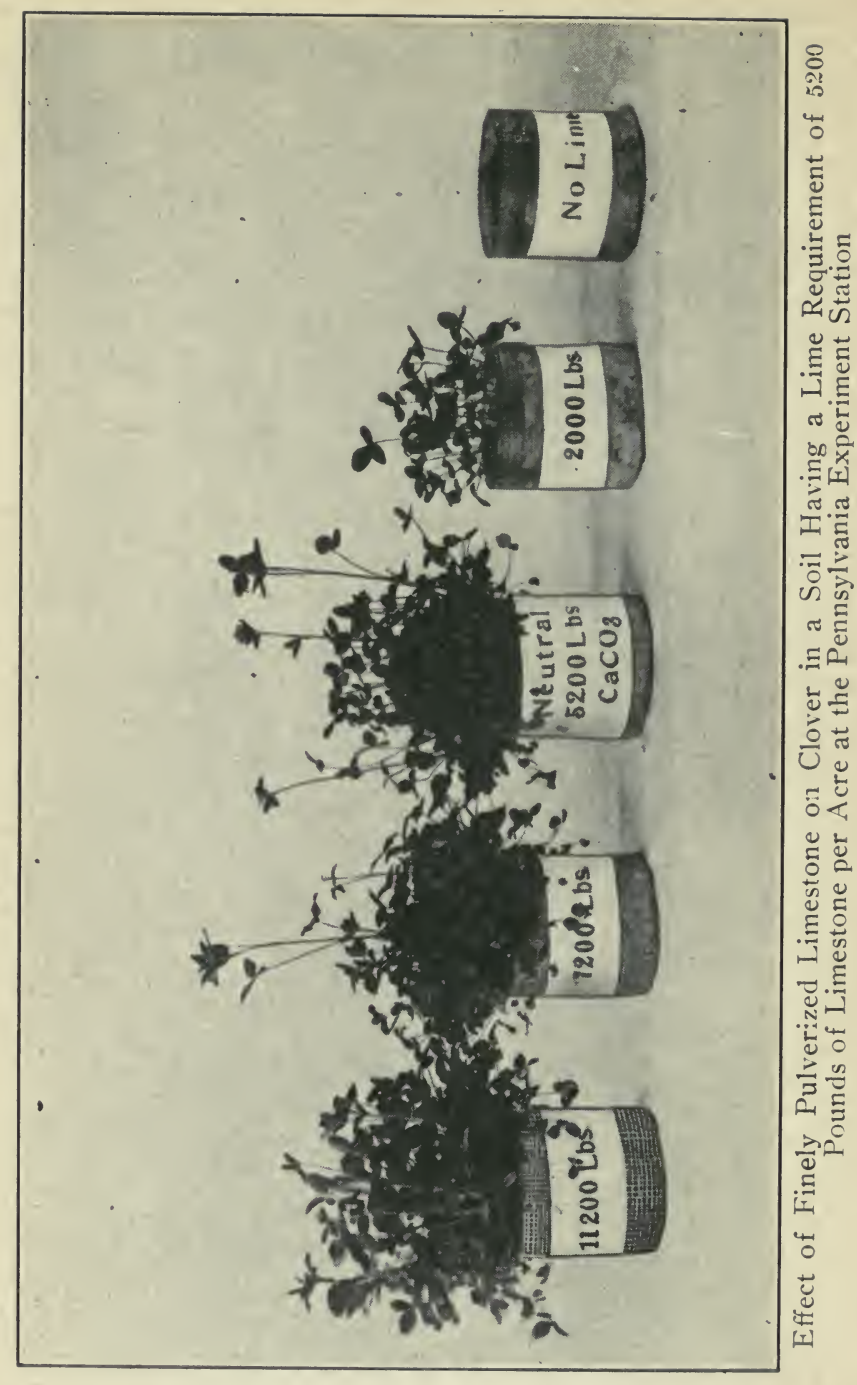


their reputation for good fighting qualities. The Clovers. Red clover can make growth in some soils that have a lime deficiency. If all other conditions are favorable, the lime requirement may exceed onehalf a ton per acre of fresh burned lime and not affect the clover adversely, but farm experience throughout the country has demonstrated that when soil acidity is only slight and clover grows with difficulty, an application rarely fails to favor the clover in a marked degree. Experience has taught the land owners to fear soil acidity when red clover does not thrive where formerly it made good growth.

The prevalence of alsike clover in a farming region is indicative of lack of lime. This clover thrives in a calcareous soil, but is more indifferent to a small lime supply than is the red clover. As red clover seedings begin to fail, the alsike gains in popularity, and where a soil is decidedly sour the alsike is most in evidence. The latter has less value to the farmer, rooting nearer the surface of the soil, and making less growth of top, but it has gained in favor with farmers as soil acidity has increased. The Grasses. Timothy is more resistant 
to acidity than red clover, but often fails to make a heavy sod where the deficiency in lime is marked. Rhode Island Bent, known as redtop, is less exacting, and where it thrives to the exclusion of timothy, or is in evidence in grass lands, the inference is fairly safe that a test would show that the soil is sour.

When Production Decreases. It is not a matter of any moment to the owner of a productive soil whether or not his soil would give an acid or an alkaline reaction under test. Returns from his labor are satisfactory. Some land in this class is not strictly alkaline. The man most interested in the effects of lime applications is the one who is not satisfied with yields. The tests for acidity have been so many throughout our eastern and central states that the owner of land which is not productive has reason for the presumption that its percentage of lime is too low. There is danger of error, and a scientific test is surer, but in most cases the land which has been reduced from a fertile to an unproductive state has lost its alkaline nature.

Naturally Thin Soils. Nature may be prodigal in supplies of nearly all the ele- 
ments of plant food to landand yet skimp its supply of lime, but naturally poor soils are quite surely in the acid class. The exceptions in our humid region are not extensive. When improvement is planned for, involving additions of organic matter and plant food, the application of lime to correct acidity is the first requirement. If such land could be given the characteristics of a limestone soil so far only as the lime factor is concerned, the building up of fertility would be relatively easy. Liming must form the foundation of a new order of things. The ability to grow the clovers and to furnish rich vegetable matter to the soil, which naturally is poor in humus, rests upon lime application first, and then upon any supply of plant food that may continue to be lacking. 


\section{CHAPTER V \\ TESTS FOR ACIDITY}

The Litmus Paper Test. A method of testing soils for acidity, which has been in use for many years, is the simple litmus paper method. Because of its simplicity and fair degree of accuracy, the litmus paper test is still used to a considerable extent in estimating the degree of acidity of certain soils. The best manner of using litmus is to place a strip of the blue paper in the bottom of a glass saucer, covering it with filter paper or other paper which is neutral-that is, paper which is neither acid nor alkaline.

A small quantity of the soil to be tested is moistened with rain or distilled water and placed on this paper. If the acid is present the blue paper will be changed to a reddish color, varying in intensity according to the degree of acidity in the soil. Two objections to the use of litmus paper are to be noted: One of these is that the red color may be produced by carbonic acid gas without a trace of more powerful acids being 
present, and this may give a wrong impression to the operator. Another objection to the use of litmus is that the degree of acidity is not accurately indicated, and therefore the farmer is sometimes at a loss to know just how much lime should be applied to make soil conditions favorable for growing crops.

A More Accurate Method. Within the last few years improved methods for determining the presence of acidity in soil have been developed. Some of these are suitable only for the chemist with his complete laboratory equipment, while others are more simple and can be used by anyone willing to exercise reasonable care.

One of the simplest and most accurate tests to date is that devised by Professor E. Truog of the agricultural experiment station of the University of Wisconsin. This test not only detects positively the presence of soil acidity, but also gives definite information as to the degree of acidity. The test is based upon the principle that when zinc sulfid comes in contact with the acid, hydrogen sulfid gas is formed, and when this gas comes in contact with lead acetate, lead sulfid, a black chemical, is formed. 
The method of making this test is simple, and consists in placing a measured quantity of soil in a flask, to which is added a solution composed of $20 \%$ calcium chlorid and $2 \%$ zinc sulfid. The mixture of soil and chemical solution is heated to the boiling point by means of an alcohol lamp, and the boiling continued for a minute for the purpose of driving off the carbonic acid gas, which is liberated first. The boiling is continued and a piece of moistened paper, previously impregnated with lead acetate, is placed over the mouth of the flask. If the soil contains acid, a chemical reaction occurs between it and zinc sulfid, and hydrogen sulfid gas is liberated. The quantity of acidity in the soil determines the quantity of gas which comes in contact with the lead acetate paper, and this determines the depth of color produced on the paper. A slight brownish color indicates the presence of very little acidity, while an intense black signifies the presence of injurious amounts of acidity. There are various degrees of coloration between these two extremes, and each gives an accurate indication as to the quantity of lime required to correct the acidity. 


\section{TESTS FOR ACIDITY}

This test is simple and inexpensive, and at the present time most county agent offices are equipped with this apparatus or a similar one for testing soils for farmers. Some newer methods are being devised, and doubtless this method will be improved upon as time passes, but the Truog test has qualities of accuracy and simplicity which will always make it valuable. 


\section{CHAPTER VI \\ SOURCES OF LIME}

Nature's Provision. Soils are composed of pulverized stone and organic matter. Much of the original stone contained little lime, and the human race would become nearly helpless if there were no stores of supply in the form of limestone, chalk, marl, etc. The day would come when the surface soil could not produce our staple crops if its loss of lime continued, and a means of replenishing the stock were not at hand. The huge deposits of limestone that have not been disintegrated by processes of weathering are assurance that the soil's need can be met forever. The calcium and magnesium in the stone are in chemical combination with carbonic acid forming carbonates, and there is an additional mixture of other earthy material that was deposited by the water when the stone was being formed, but much limestone possesses an excellent degree of purity.

Confusion Respecting Forms. In the public mind there is much confusion re- 


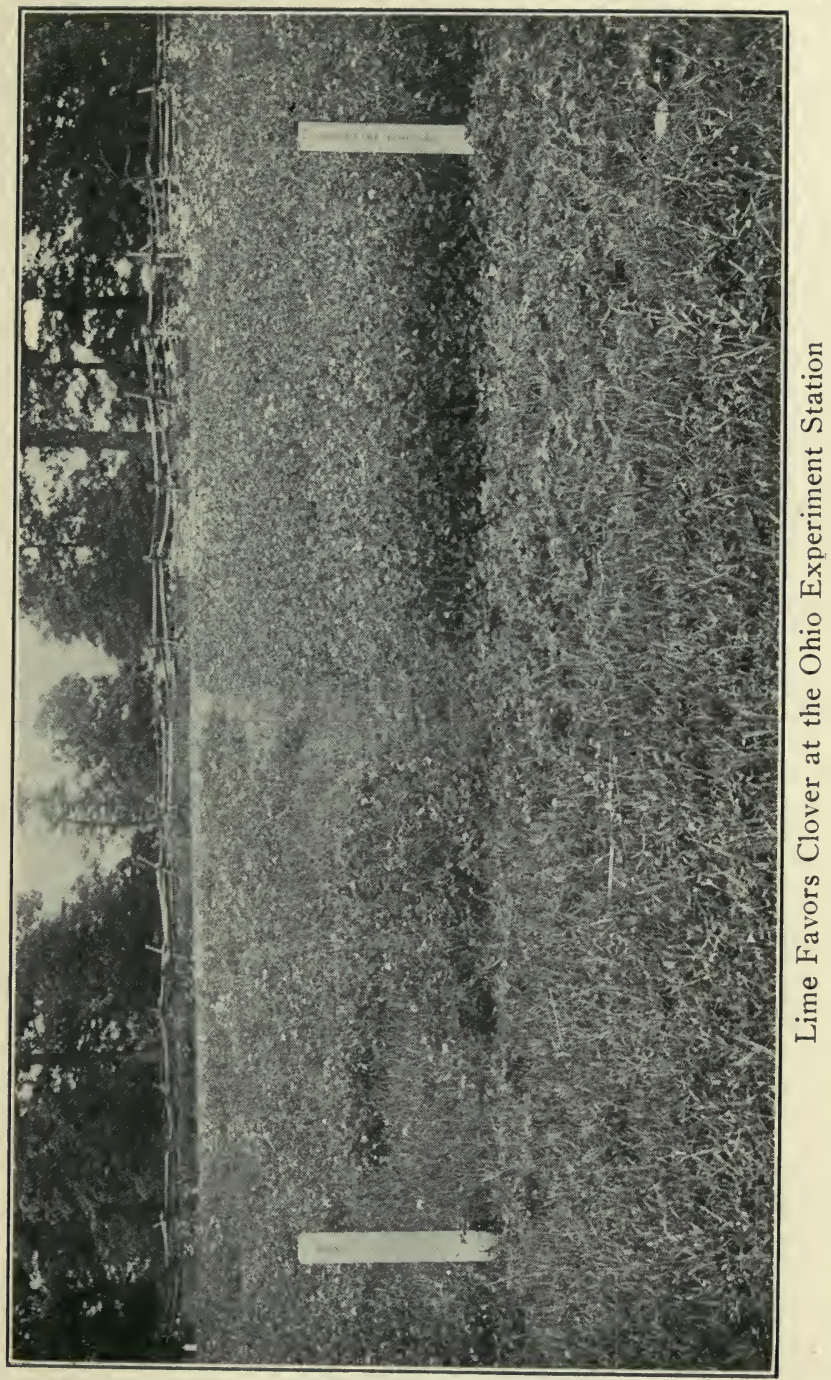




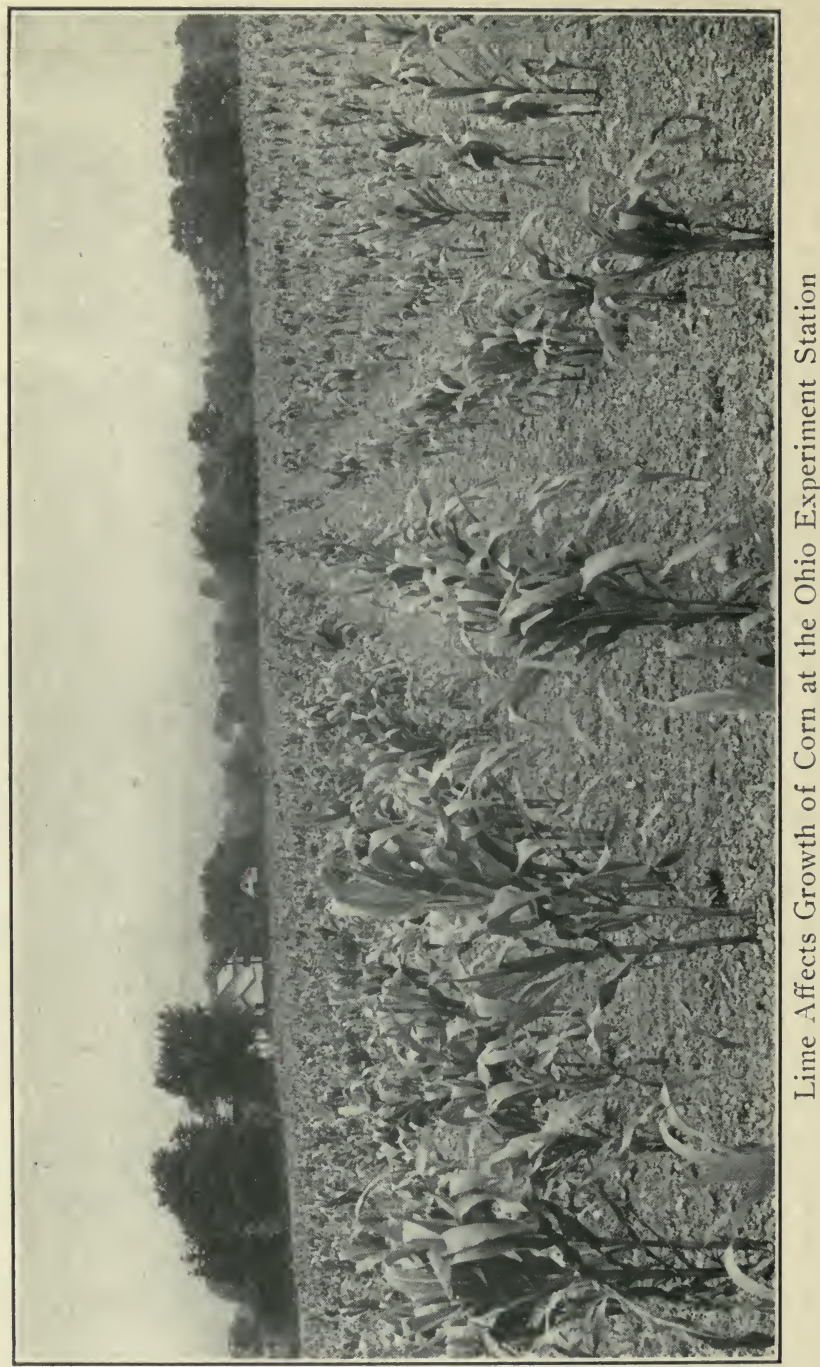


specting the sources and forms of lime most to be desired. Wood ashes appealed to people, especially in an early day in our agriculture, partly because the ashes were so universally present that tests had been made voluntarily and otherwise in millions of instances. The value of such tests had been obscured by the fact that the ashes contained potash, and much of the credit of any good effect was attributed to that fact. It has been generally known, however, that lime in peculiarly effective form is in wood ashes, and the favor in which ashes have been held rested not a little upon the curious preference for an organic source of all soil amendments. This is seen in the case of direct fertilizers.

Dealers' Interests. The doubts regarding the wisdom of selecting any one form of lime for the betterment of soil conditions have been promoted very naturally by the conflicting interests of men who would furnish the supply. Some dealers in fresh burned lime have asserted that it was folly to expect any appreciable result from the use of unburned limestone. The manufacturer of ground limestone has pointed out the possibility of injuring a soil by the use 
of caustic lime, and oftentimes has so emphasized his point that farmers have become unwilling to apply fresh or waterslaked lime to their land. Manufacturers of hydrated lime in some instances have made a confused situation worse by insisting upon the claim that there was a fertilizing quality in their goods. Some dealers in lime marls have been unwilling to have the value of their goods rated according to the content of carbonate of lime, and have emphasized the value of fine division of the particles and the absence of any caustic properties. The presence of shells, evidencing an organic source of the material, has helped in the appeal to buyers.

The rightful place of magnesia, and the possible danger of injury from its use, have been a fruitful cause of perplexity, making price per ton only a secondary consideration to the man wanting to supply his soil's needs.

Scientists' Failure to Agree. It is only fair to say that much of the doubt and indecision on the part of the public is directly attributable to the conflicting statements of our scientists. It should be borne in mind that careful investigation in respect to the 
relative values of the various forms and sources of lime has been confined largely to the short period of time that has elapsed since recognition of the lime deficiency of our country's soils. Our agricultural literature contained little about soil acidity 20 years ago, and our experiment station tests afford only relatively recent results. Some knowledge of sour soils and the efficacy of lime in their amendment is nearly as old as the history of agriculture, it is true, but answers to the questions uppermost in the minds of men wanting to apply lime to land have been sought only within recent years. The variation in soil types, and in sources of lime, and in preconceived ideas of men drawing conclusions from incomplete data may easily account for failure of our soil scientist's to be in the close agreement in statement that would remove all confusion in the public mind. However, the agreement respecting the facts is becoming better assured with every added year of investigation, as a study of station bulletins shows. 


\section{CHAPTER VII}

\section{DEFINITIONS}

Technical Terms. The practical man uses a great number of technical terms in his own field of labor, and often fails to recognize the fact that they are technical, and may be puzzling to many other people. He uses such terms for the sake of accuracy, desiring to express to his fellow-workmen exactly what he means. The farmer, stockman, carpenter, banker - all have command of such terms, and need them, but the chemist who, in a way, must come even nearer to accuracy in expression, finds that many people who want his assistance do not care to master and use any of his terms. Failure to do so compels misunderstanding. Anyone who is interested in the right use of lime should be willing to add a few of the chemists' technical terms to the scores in his own line of work that he uses constantly, and thus let the whole matter of liming land come to appear more simple to him. Acquaintance with a few terms is necessary to 
any understanding of statements of analyses upon which purchase should be made.

An Element is a substance that cannot be divided into simpler substances. The number of elements necessary to the growth of plants is small, and of this number calcium is one and magnesium is another.

Compounds. We do not find these elements merely mixed with other elements to form a soil. They unite in definite proportions by weight to form chemical compounds. As conditions change, many of these compounds undergo change, giving up one element, or group of elements, and uniting with another element or group from a different compound. Heat, moisture and the action of bacteria are factors in promoting the changes. There is no more restless activity than may be found among the elements composing a productive soil.

Calcium is an element which will unite with oxygen and carbon dioxide to form a compound known as calcium carbonate. The chemist's symbol for calcium is $\mathrm{Ca}$.

Calcium Oxide is a compound left after the burning of limestone, and is known as fresh burned lime, or quick lime. Its formula is $\mathrm{CaO}$. It contains, when pure, 
40 parts of calcium and 16 parts oxygen by weight.

Carbon Dioxide is a compound whose formula is $\mathrm{CO}_{2}$.

Calcium Carbonate, known also as carbonate of lime, has a definite composition, containing, when pure, 56 parts $\mathrm{CaO}$ and 44 parts $\mathrm{CO}_{2}$. It is known to the chemist as $\mathrm{CaCO}_{3}$, and forms practically all of very pure limestones. Impure limestones contain some earthy materials that became mixed with the lime carbonate when the rock was being formed.

Calcium Hydroxide is a compound made by permitting calcium oxide to combine with water, and is known as lime hydrate. It contains $5^{6}$ parts by weight $\mathrm{CaO}$ and 18 parts water, and has the formula $\mathrm{Ca}(\mathrm{OH}) 2$. Magnesium is an element, and is found in magnesium carbonate, a compound that is effective in correcting soil acidity.

Magnesian Limestone. Magnesium carbonate is usually found in combination with calcium carbonate, and when about 47 per cent of the total carbonates is magnesium carbonate, the limestone is known as dolomite.

Ground Limestone is the stone pulver- 
ized so that it can be distributed. It is carbonate of lime $\left(\mathrm{CaCO}_{3}\right)$, or a combination of calcium and magnesium carbonate, and in a way has a right to be designated as "lime," but such use leads to confusion.

Fresh Burned Lime. Calcium oxide $(\mathrm{CaO})$ formerly was accurately designated as "lime," but the words "fresh burned" are often prefixed to prevent confusion with lime carbonate or the hydrate. It is known as "lump lime," "caustic lime" and "stone lime."

Ground or Pulverized Lime. Fresh burned lime may be ground fine, so that it can be spread on land without slaking. This product should not be confused with ground limestone or hydrated lime. Fresh ground lime is worth nearly twice as much per ton as ground limestone, but some of the product on the market is far from pure. There is opportunity to grind up unburned and waste material with the caustic lime, and this form of lime usually contains some hydrated material.

Hydrated Lime is the compound formed. by the action of water or steam on fresh burned lime.

Air-Slaked Lime is a compound formed 


\section{RIGHT USE OF LIME IN SOIL IMPROVEMENT}

by the action of carbon dioxide from the air on hydrated lime, and its formula is $\mathrm{CaCO}_{3}$, which is that of pure limestone. 


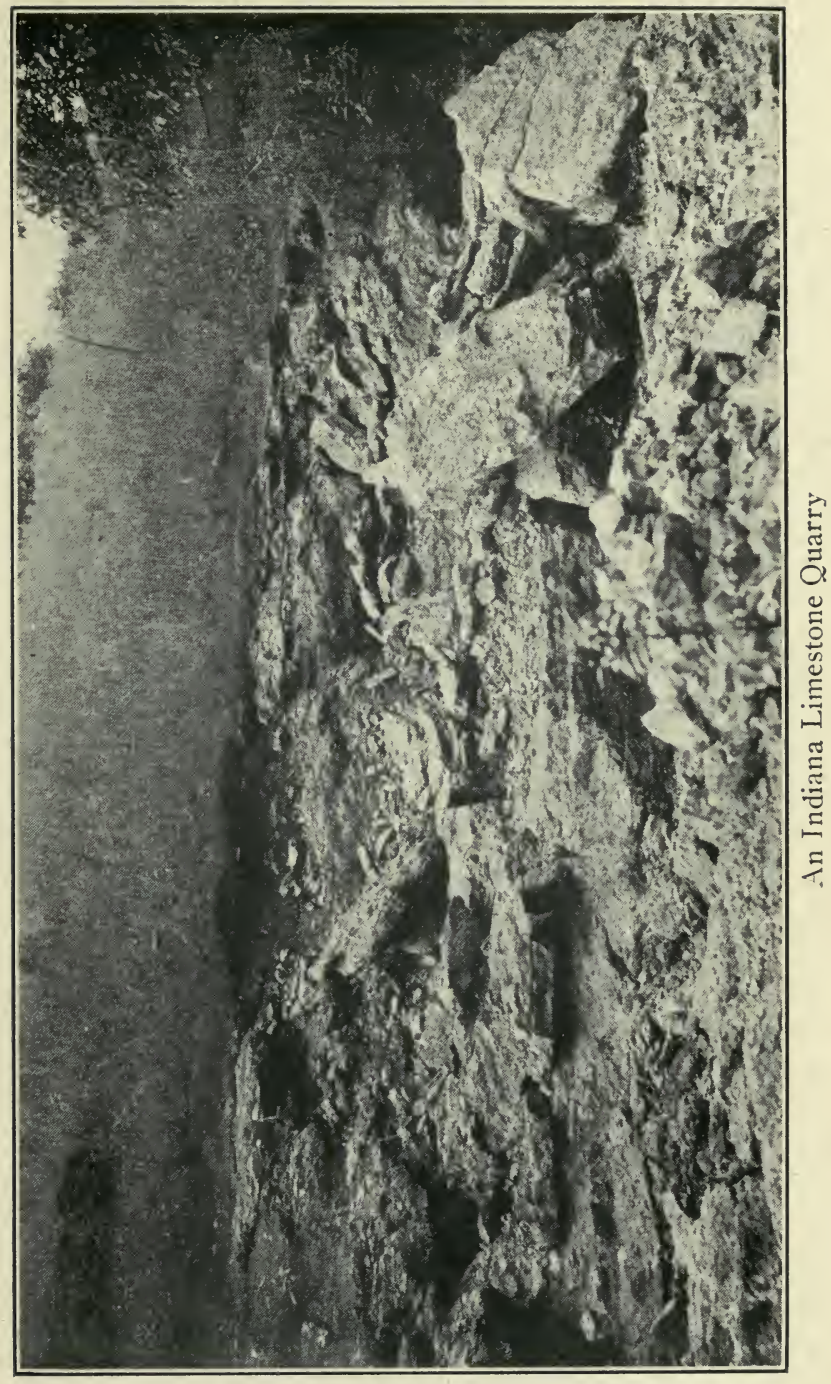




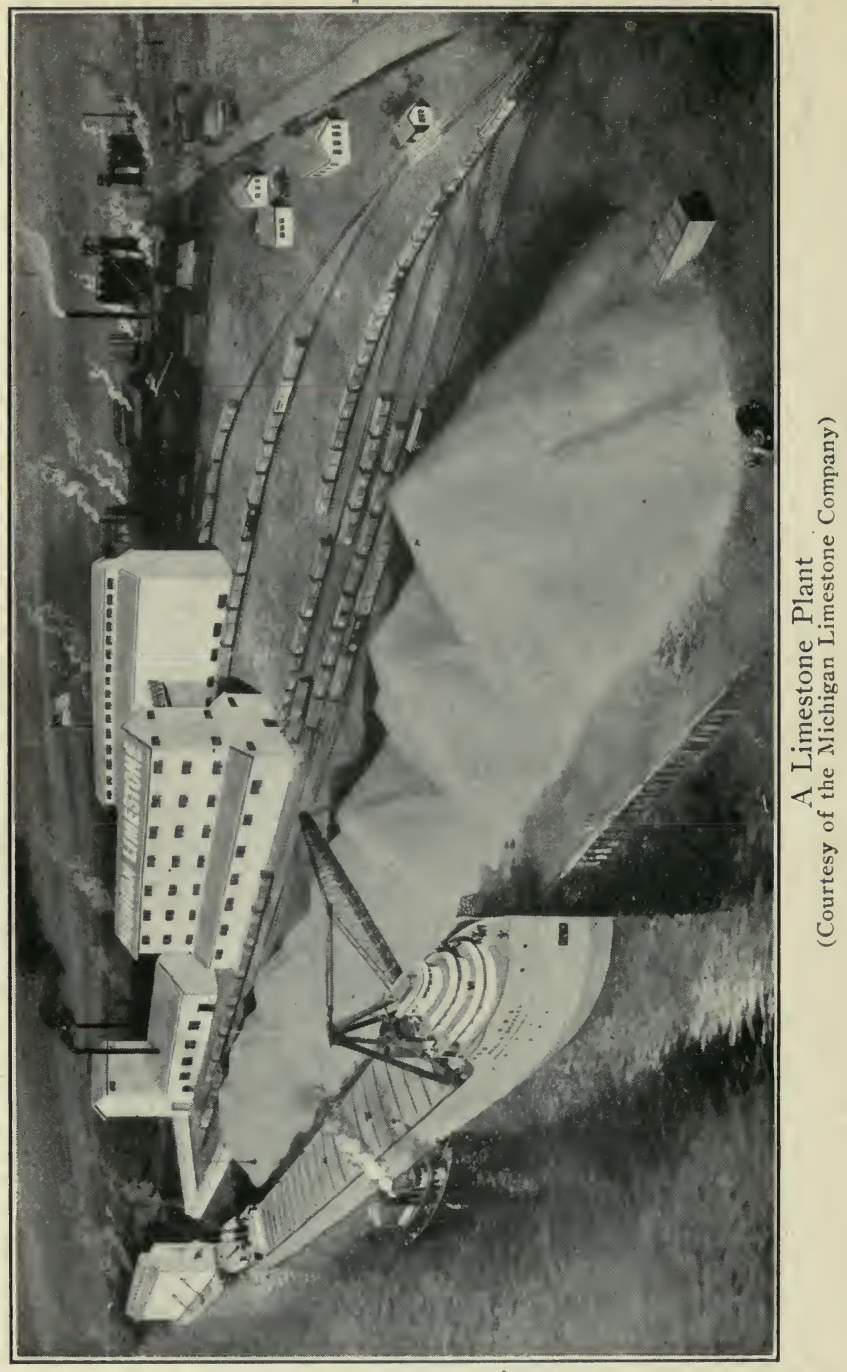




\section{CHAPTER VIII \\ GROUND LIMESTONE}

Variation in Quality. Limestones vary widely in purity. They were formed under water, and clay and sand were laid down with the lime in such quantity in some cases that the resulting stone is not worth handling for soil improvement. A stone that is practically all carbonate of calcium, or a combination of calcium and magnesium, is wanted because it is these two elements that give value to the material. If a poor stone is used, too much waste matter must be handled. Twenty-five per cent more ground limestone of $80 \%$ purity must be applied than would be required in the case of an absolutely pure limestone. Any stone above $90 \%$ pure in carbonate of lime and magnesia is rated as good, but the best stone runs from $96 \%$ to $99 \%$.

Limestones vary greatly in ability to resist disintegration, and this variation is a big factor in determining the agricultural value of ground limestone that has not been reduced to a fine powder. Particles of a 
hard limestone may lie inert in the soil for many years. Hardness also affects the cost of grinding.

A Matter of Distribution. Nature has used various agencies in reducing limestone for the making of soils. The stone contained its lime in carbonate form, and when reduced to good physical condition for distribution it helped to make highly productive land. We know that lime carbonate does the needed work in the soil so far as correction of acidity is concerned, but in the form of blocks of limestone it has no particular value to the land. Burning and slaking afforded to man a natural means of putting it into form for distribution, and it is only within recent years that the pulverization of limestone for land has become a business of considerable magnitude. The ground limestone used on land continues to be in part a by-product of the preparation of limestone for the manufacture of steel, glass, etc., and the making of roads, the fine dust being screened out for agricultural purposes. These sources of supply are very inadequate, and too remote from much land that requires treatment. Large plants have been established in vari- 
ous parts of the country for the purpose of crushing limestone for use on land, and quite recently low-priced pulverizers for farm use have come upon the market and are meeting a wide need.

Low-Priced Pulverizers. A serious drawback to the liming of land is the transportation charge that must be paid where noavailablestone can befound in the region. Great areas do have some beds that should be used, and a low-priced machine for pulverizing it is the solution of the problem. Such a machine must be durable, have ability to crush the stone to the desired fineness and be offered at a price that does not seem prohibitive to a farmer who would meet the demands of a small farming community. In this way freight charges are escaped, and a long and costly haul from a railway point is made unnecessary. The limestone of the locality will be made available more and more by means of this type of machine, and the inducement to correct the acidity of soils will be given to tens of thousands of land-owners who would not find it feasible to pay freight and cartage on supplies coming a long distance. There should be a market many times greater than now 
exists for the product of all large plants, while the number of small pulverizers multiplies rapidly. The very large areas that have no limestone at hand must continue to buy from manufacturers equipped to supply them, and farmers within a zone of small freight charges should be able to buy from such manufacturers more cheaply than they could pulverize stone on their own farms.

An individual, or a group of farmers, will buy a machine for pulverizing limestone at a cost of a few hundred dollars when costly equipment would be out of the question. If he has a bed of limestone of fair quality, and the soil of the region is lacking in lime, an efficient grinder or pulverizer solves the problem and makes prosperity possible to the region. Within the last few years much headway has been made in perfecting such machines, and their manufacturers have them on the market. Any type should be bought only after a test that shows capacity per hour and degree of fineness of the product. As a high degree of fineness is at the expense of power or time, and as the transportation charge on the product to the farm is small, there is no re- 
quirement for the fineness wanted in a highpriced article that must be used sparingly.

The aim should be to store in the soil for a term of years, and the coarse portion is preferable to the fine for this purpose because it will not leach out. The heavy application will furnish enough fine stuff to take care of present acidity. If nearly all the product of such a pulverizer will pass through a Io-mesh screen, and the amount applied is double that of very fine limestone, it should give immediate results and continue effective nearly twice as long as the half amount of finer material. There could hardly be a practical solution of the liming problem for many regions without the development of such devices for preparing limestone for distribution, and it is a matter of congratulation that some manufacturers have awakened to the market possibilities our country affords. 


\section{CHAPTER IX}

\section{STORING LIME IN THE SOIL}

Liberal Use of Limestone. Land never does its best when skimped in any way. As we raise the percentage of carbonate of lime in land that naturally is deficient, we give increasing ability to such land to take on some of the desirable characteristics of a limestone soil. It is poor business to be making a hand-to-mouth fight against a state of actual acidity unless the cost of more liberal treatment is prohibitive. The most satisfactory liming is done where the expense is light enough to justify the free use of material. When this is the case, extreme fineness of all the stone is undesirable. There is the added cost due to such fineness and no gain if the finer portion is sufficient to correct the acidity, and the coarser particles disintegrate as rapidlv as needed in later years.

Loss by Leaching. Another valid argument against extreme fineness of the stone used in liberal applications is the danger of loss by leaching. Soils are so variable in 


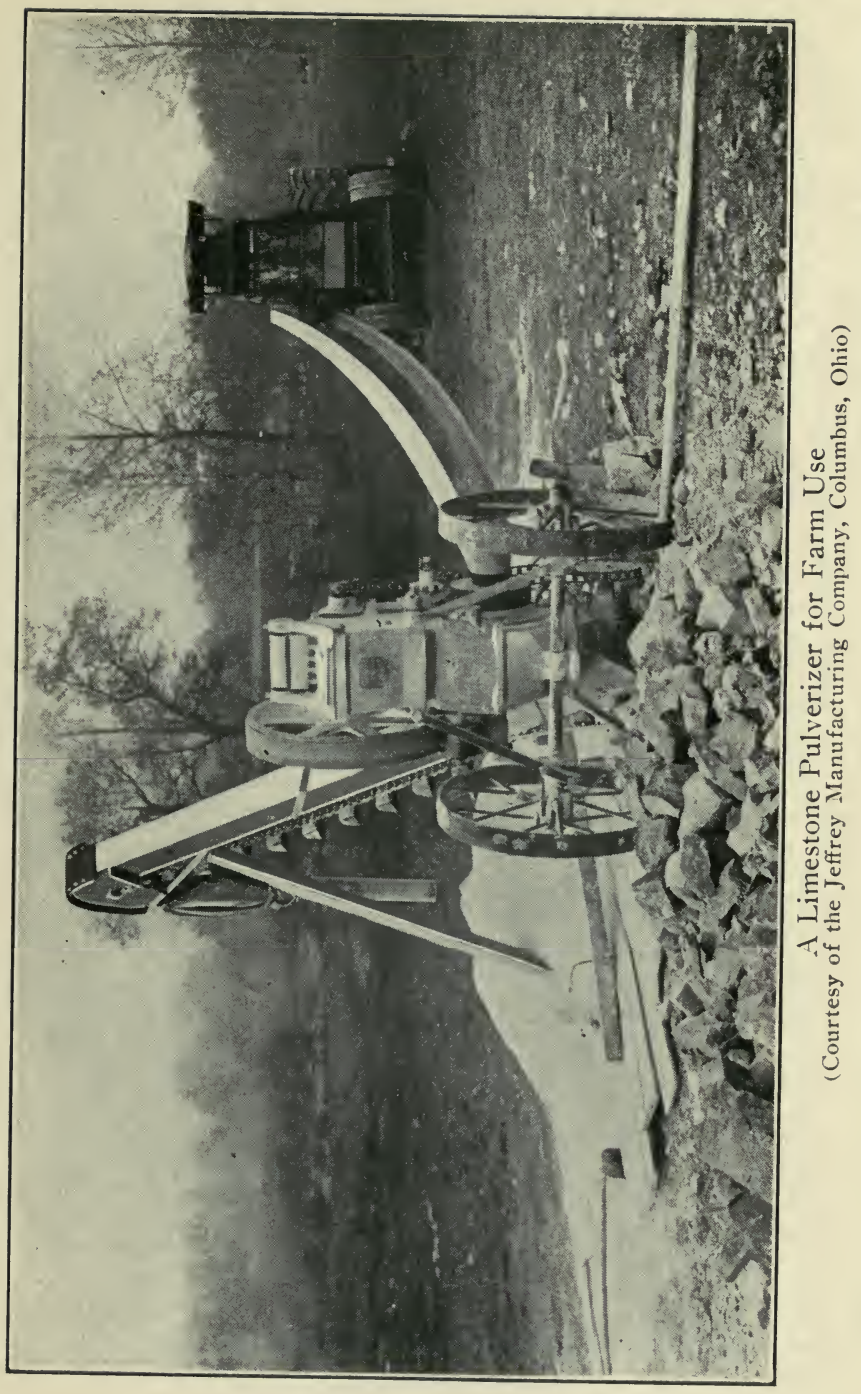




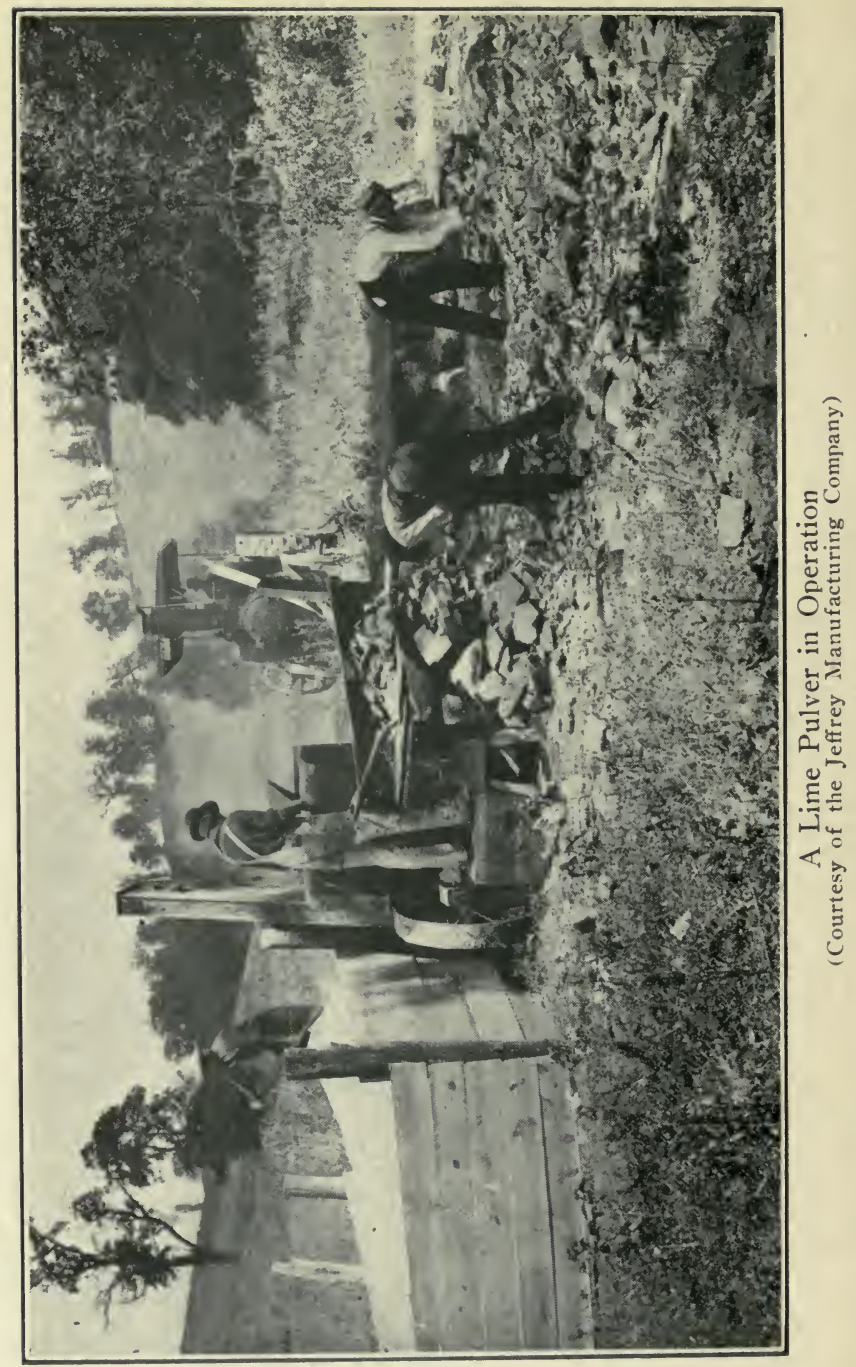


their ability to hold what may be given them that it is idle to offer any estimate on this point. The amount of lime found in the drainage waters of limestone land teaches no lesson of value for other land, the excessive loss in the former case being due oftentimes to erosion that creates channels through the subsoil,.through which soil and lime pass.

But we do know the tendency of lime to get away, and the use of several tons of fine stone per acre may easily be followed by loss in many types of soil. It is wholly reasonable to believe that some portion of such an application should be coarse enough to stay where put until needed by exhaustion of the finer portion. It is upon this theory that coarser material often is preferred to the very finest.

What Degree of Fineness? Assuming that the farmer is in a position to store some carbonate of lime in his land for future use, giving the soil an alkaline character for five or Io years, the degree of fineness of the stone is important, partly because there will be distinct loss by leaching from many types of soils if all the material is fine as dust, and specially because less finely pul- 
verized material can be supplied him at a lower price per ton. Much by-product in the manufacture of coarse limestone for other purposes contains a considerable percentage of material that would not pass through a $60-$, or $40-$, or Io-mesh screen, but it does contain a big percentage of immediately available lime, and a more complete pulverization of this by-product would add greatly to its cost.

It is quite possible that a ton of such stone may be bought at a price that would cover the value only of the fine portion, estimated on the basis of the prevailing price of finely ground material, the coarse material being obtained without any cost at all. It is this situation, or an approach to it, that leads some authorities to become strenuous advocates of the use of coarsely pulverized stone. The advice is right for those who are in a position to accept it. If the money available for liming an acre of land can buy all the fine stone needed for the present and some coarser stone mixed with it for later use by the soil, the purchase is much more rational than the investment of the same amount of money in very fine stone that has no admixture of coarser material. If the 
investment in the former case is larger than in the latter, it continues to be good business up to a certain point, and the room for some uncertainty is wide enough to provide for much difference in judgment.

Quality of the Stone. Another factor of uncertainty is the hardness of the stone. 'A limestone may have such flinty characteristics that a piece barely able to pass through a IO-mesh screen will not disintegrate in the soil for years, and there are other types of limestone that go into pieces rapidly. The variation in quality of stone accounts for no little difference in opinion that is based upon limited observation.

Using One's Judgment. It is evident that no hard and fast rule respecting fineness may be laid down, and yet a rather definite basis for judgment is needed. There is much good experience to justify the requirement that when all ground lime is high-priced in any section for any reason, and the amount applied per acre is thereby restricted, the material should be able to pass through a screen having 60 wires to the linear inch, and that the greater part should be much finer. Usually some part of such stone will pass through a 200-mesh screen. 
When a limestone on the market will not meet this test, some concession in price should be expected. If the stone is not very flinty, a 40-mesh screen may be regarded as affording a reasonably satisfactory test.

An increasing percentage of coarser material makes necessary an increase in amount to meet the lime deficiency, and a distinct concession in price is to be expected when a ro-mesh screen is used in testing. At the same time a careful buyer will use a 60mesh screen to determine the percentage that probably has availability for the immediate future. A coarsely ground article, containing any considerable percentage that will not pass through a IO-mesh screen, must sell at a price justifying an application sufficient to meet the need of the soil for a long term of years, as the greater part has no immediate availability, and only a heavy application can provide a good supply for immediate need.

New York State Experience. A bulletin of the New York agricultural experiment station, published early in I9I7, calls attention to the rapid increase in demand for ground limestone in New York. Within the last five years the number of grinding 
plants within the state had increased from one to 56 , and more than a dozen outside plants are shipping extensively into the state. The bulletin says: "Farmers who have had experience with the use of ground limestone are as a rule satisfied with only a reasonable degree of fineness, and are able to judge the material by inspection. When limestone is ground so the entire product will pass a Iomesh (or $2 \mathrm{~mm}$.) sieve, the greater part of it will be finer than a 40 -mesh (or $\mathrm{T} / 2 \mathrm{~mm}$.) sieve. . . There are now in operation in this State more than a dozen small portable community grinders; they are doing much to help solve the ground limestone problem and their use is rapidly increasing. In the practical operation of these machines they grind only to medium fineness (2 $\mathrm{mm}$.). To insist upon extreme fineness is to discourage their use."

This State experiment station is only one of many scientific authorities approving the use of limestone reduced only to such fineness that it will pass through a ro-mesh screen, the cost of the grinding being sufficiently small to permit heavy applications. 


\section{CHAPTER X}

\section{FRESH BURNED LIME}

An Old Practice. The beneficial effect of caustic lime on land is mentioned in some ancient writings. Burning and slaking afforded the only known method of reducing stone for use in sour soils. Lime in this form not only is an effective agent for correcting soil acidity, but it improves the physical condition of tough and intractable clays, rendering them more friable and easy of tillage. Caustic lime also renders the organic matter in the soil more quickly available, an increase in yield quickly following an application. These three effects of burned lime brought it into favor, and a rational use would have continued it in favor.

Irrational Use. The ability of caustic lime to improve the physical condition of land and to make inert plant food available has led many farmers to treat it as a substitute for manure, sods and commercial fertilizers. Immoderate use gave increased crop yields for a time, and the inference was 
easy that lime could displace the old sources of plant food supplies. It became the custom in some regions to apply 200 to 300 bushels per acre to stiff limestone soils that had no lime deficiency, as a test for acidity would have shown. The lime not only made some mineral plant available, but it attacked the organic matter of the soil, making it ready for immediate use and leaving the land deficient in humus. Wherever stable manure and clover sods were not freely used, the heavy application of caustic lime was followed ultimately by decline in productive power. Such practice has come under the condemnation of people who have not seen that the ill results have no relation to the rational use of lime.

What Lime Is. There is abundant evidence that pulverized limestone, or lime marl, or oystershell, or any other form of carbonate of lime, corrects soil acidity and helps to make a soil productive. It is good, no matter whether nature mixed the lime carbonate with clay, etc., to make a choice limestone soil, or man applied it. Fresh burned lime is only the stone after some worthless matter has been driven off by use of heat. The limestone, carbonate of lime, 
is represented by the formula $\mathrm{CaCO}_{3}$. When heat is applied under right conditions the carbon dioxide, $\mathrm{CO}_{2}$, is driven off, and there remains $\mathrm{CaO}$, which is calcium oxide, called fresh burned lime.

If there were Ioo pounds of the stone, and it was absolutely pure, 44 pounds would escape in form of the carbon dioxide, which had no value, and $5^{6}$ pounds would remain. The $5^{6}$ pounds calcium oxide, or fresh burned lime, have the same power to correct acidity as this same material had when it was bound up in the roo pounds of limestone. The 44 pounds were driven off by heat, while if the limestone had not been burned the 44 would have separated from the 56 pounds in an acid soil, leaving the actual lime to do the needed work of correcting acidity.

Affecting Physical Condition. While burning the stone does not affect the ability to correct acidity, it does increase the power to make a stiff soil friable and to bind a sandy soil. No one may say how much this power to influence soil texture is increased, but it is marked, and when improved physical condition is the chief reason for applying lime, there is no question that fresh 
burned material is to be preferred to pulverized stone or marl, or any other carbonate form. A light application is not markedly effective in this respect, and the chief use for this purpose has been in limestone areas that may not have had any lime deficiency, but did have a stiff soil. The presence of the stone in great quantity for burning on the farm made heavy applications possible.

Using Up Organic Matter. The presence of carbonate of lime in the form of pulverized limestone or marl favors the disintegration of any organic matter, but the action is so slow that it may not be observed. While the use of limestone in manure piles is inadvisable for this reason, the loss is not comparable to that resulting from mixing caustic lime with manure. The caustic lime in a soil hastens decay of vegetable matter in a degree impossible to the limestone or marl. Irrational use of the former has produced such destructive action in many instances that the failure to add manure or heavy sods for a long term of years has led to heavy decline in producing power.

We are naturally so lacking in judicial 
temper that opinion has swung violently from favor to disfavor. As most soils need organic matter, we seize upon the thought that anything evidently inclined to use it up is an evil. The purpose of tillage is in no small degree to bring about disintegration and resulting exhaustion of vegetable matter. The latter is a storehouse of plant food, and some of it is needed to feed the crop desired. Tillage is no more to be commended for this purpose than a quantity of lime equivalent in power to do the needed work. Excepting the case of raw soils rich in the remains of plants, most land hardly needs lime for this purpose, it may be, the tillage required for making a seed bed retentive of moisture and for control of weeds being effective, but the point is emphasized that the disintegration of organic matter into available plant food is one of the chief aims of a good farmer. It is only the excessive use of caustic lime that causes loss.

The use of caustic lime in sufficient amount to correct all acidity, and the use of such material to free plant food in humus sufficiently to produce heavy sods, are just as good farm practices as drainage and the application of manure. 


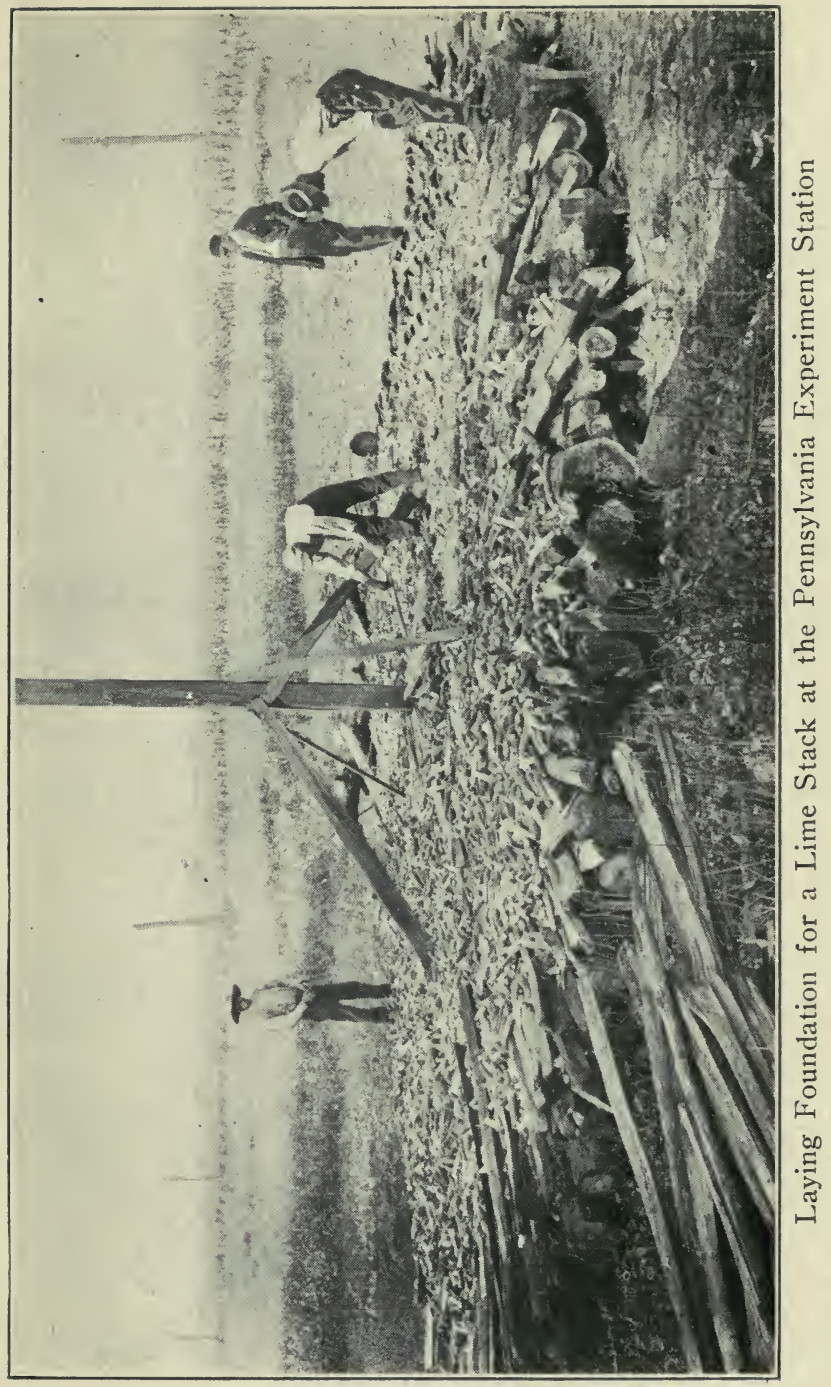




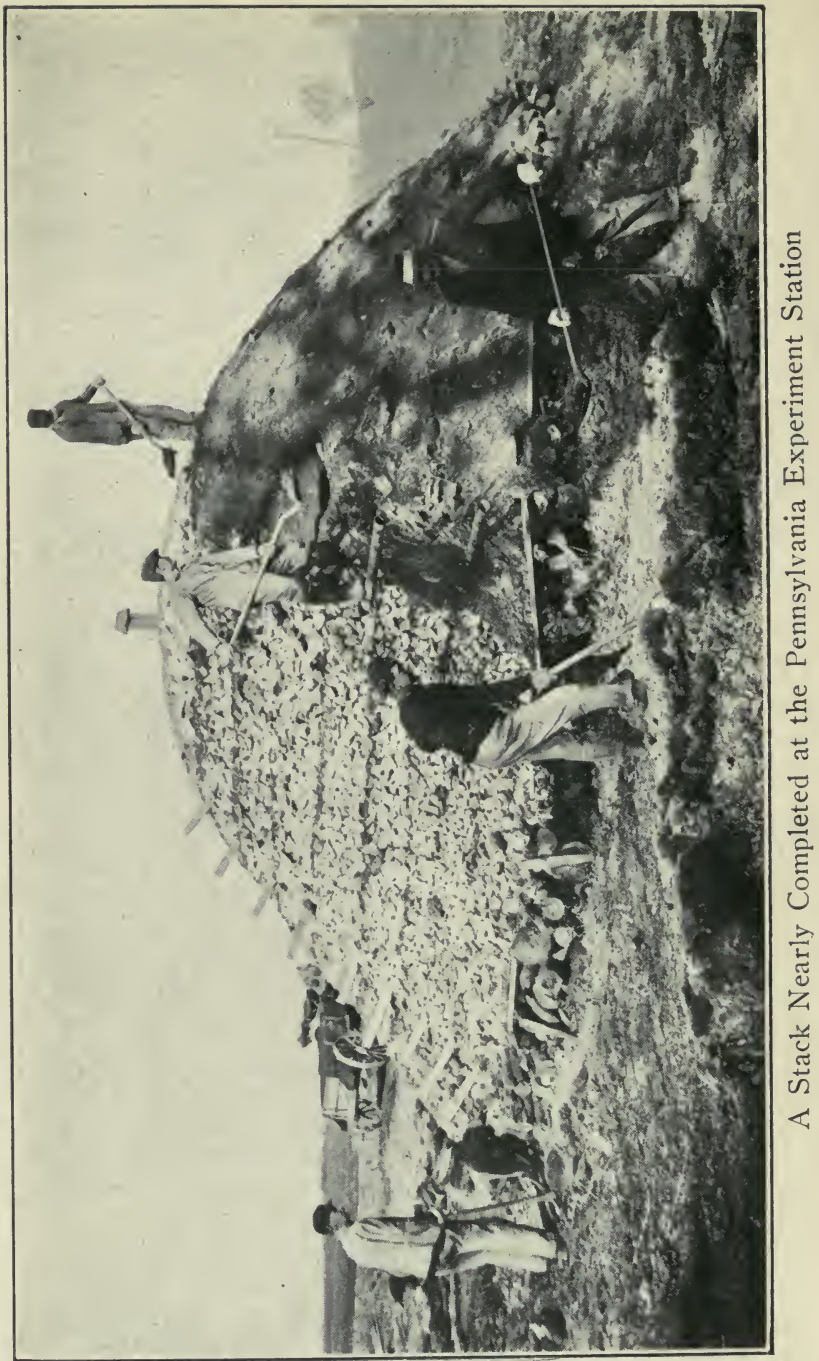




\section{CHAPTER XI BURNING LIME}

Methods of Burning. Limestone contains the calcium and magnesium that must be the chief source of supply of American soils, though marls, ashes, etc., have their place. The burning of the stone has been the leading means of bringing it to a condition of availability to the soil, excepting, of course, the vast work of disintegration carried on through all the ages by nature. Pulverization of the rock by machinery for use on land is recent.

The devices for burning are various, a modern lime plant containing immense kilns, cylindrical in form, the stone being fed into them at the top continuously, and the lime removed at the bottom. A large part of the lime that is sold for use on land is made in plants of his kind. Some is burned in kilns of cheap construction, but a traveler through a limestone country finds few such kilns now in use.

The Farm Lime Heap. A common method of producing lime for farm use has 
been, and continues to be, a simple and inexpensive one, involving the use only of wood, coal and limestone, with earth as a covering. Dr. Wm. Frear, chemist of the Pennsylvania station, in Bulletin 26r of the Pennsylvania department of agriculture, describes a method of burning lime on the farm as follows: "A convenient oblong piece of ground is cleared, and leveled if need be, to secure a fit platform. Upon this level is placed a layer or two of good cord wood, better well seasoned, arranged in such manner as to afford horizontal draught passages into the interior of the heap. Between the chinks in the cord wood, shavings, straw or other light kindling is placed. The stone having been reduced to the size of a double fist, sometimes not so small, is laid upon the cord wood, care being taken to leave chinks between the stones just as between the bricks in a brick kiln. It is preferred that this layer of stone should not exceed six to ten inches in thickness.

"In some cases, temporary wooden flues, filled with straw, are erected, either one at the center or, if the heap is elliptical, one near each end, and the stone and coal are 
built up around them; thus, when they are burned out, a chimney or two is secured, which may be damped by pieces of stone or sod. Upon this first layer of stone is spread a layer of coal, and upon that a thicker layer of stone ( 12 inches), and so on, coal and stone alternating until the heap is topped with smaller stone. The largest stones should be placed near the top of the heap, but not near the outside, so that they may be exposed to the highest heat. The proportion of coal is diminished in the upper layers, the effort being to distribute one-half of the total coal employed in the two lower layers, so as to secure the highest economy possible in the use of the fuel.

"Fire is then kindled in the straw or shavings; when the flames have communicated themselves to the cord wood and lowermost layer of coal, and tongues of flame shoot out from the crevices in the sides of the heap, earth, previously loosened by a few turns of the plow about the heap, is rapidly spread over the entire heap, thus damping the drafts and retarding the combustion. Steam and smoke slowly escape during the first hours, but later the entire heap, including the outer covering of earth. 
is heated to a dull red glow. The burning goes on slowly for several days, the interior often being hot for several weeks. When the lower portion of the heap has reached an advanced stage of calcination, a portion of the outer layer of lime sometimes slips down; if so, a fresh covering of earth must promptly be applied at the exposed point; otherwise it will serve as a vent for the heat, and the top and other sides will fail of proper calcination." 


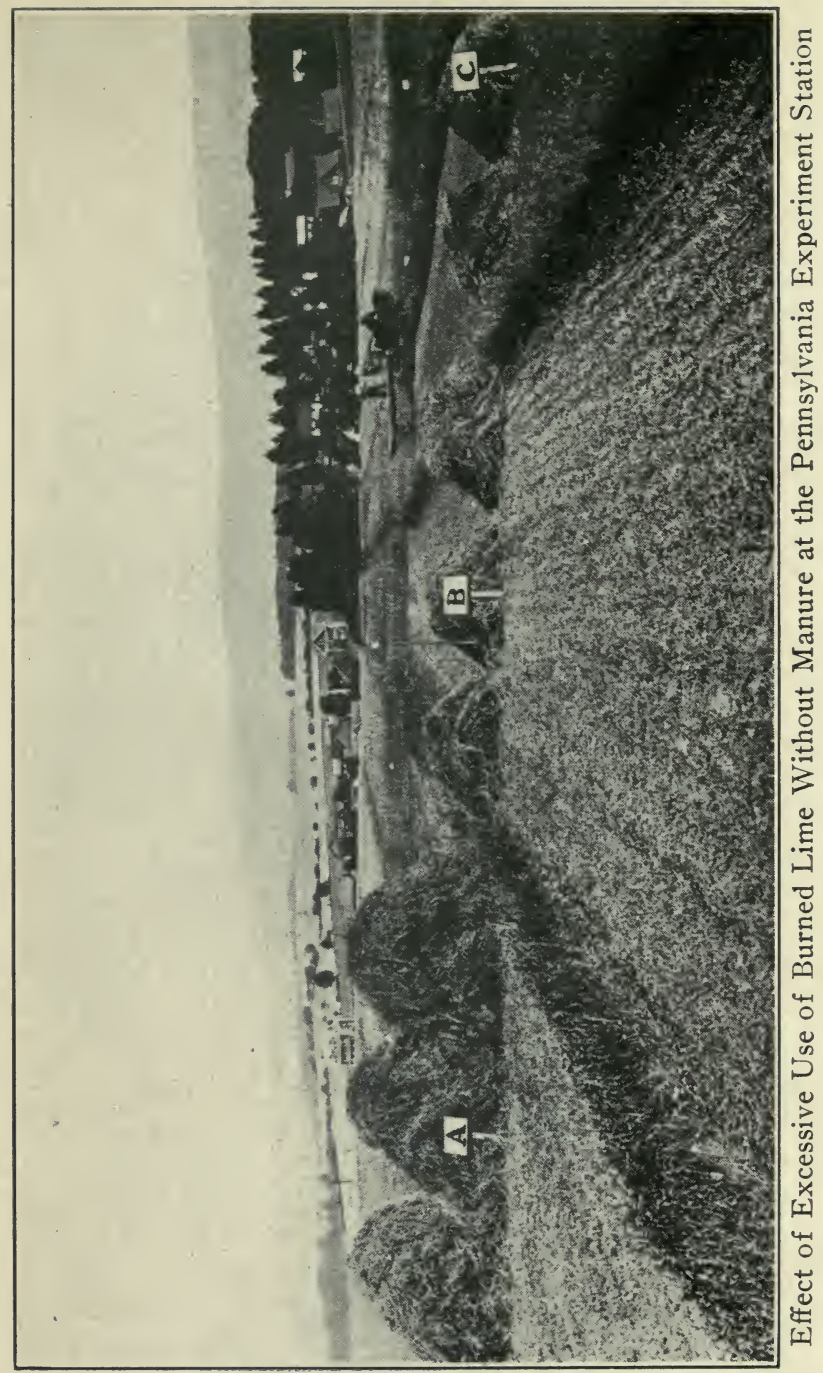




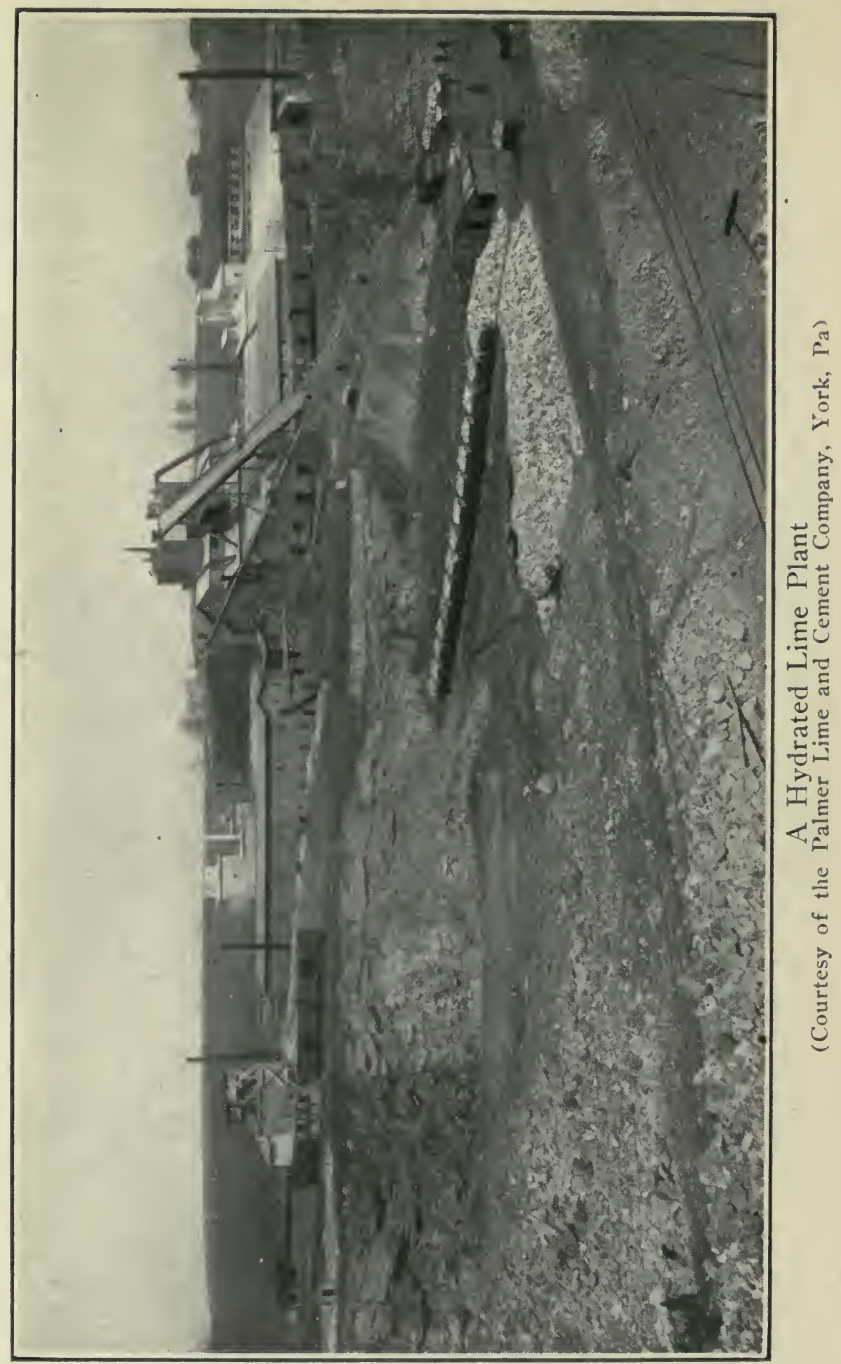




\section{CHAPTER XII \\ LIME HYDRATE}

Slaking Lime. The usual means of reducing fresh burned stone lime to a condition that makes even distribution upon land possible is by slaking. A few years ago considerable effort was made to create a market for lime pulverized by machinery, but the difficulty in excluding the moisture of the air so that packages would not burst has been in the way of developing a market. Slaking, by the addition of water to the fresh burned lime, is the common method of getting the required physical condition. When the slaking is done on the farm, the custom has been to distribute the lime in small piles in the field, placing the piles at such convenient distance apart that the lime, after slaking, could be spread easily with a shovel.

The water for slaking comes from rains, or from moisture in the air and earth. The method is wasteful and can be justified, if ever, only where farm-burned lime costs little per ton, and the nature of the soil is 
such that a relatively heavy application can be safely made. The distribution is necessarily uneven, and if the required amount goes upon all the surface, a great excess is sure to go upon a portion of it. Very often an excess of water puddles much of the lime in the pile, and lumps may be seen lying in ineffective form in the soil for years. The practice is responsible for much of the excessive application that brought the use of caustic lime into disrepute.

Slaking in Large Heaps. A preferable method is to put the lime in flat heaps of large size and about four feet deep, so that water may be applied or advantage be taken of rainfall. The value of the lime is so great that one can well afford to draw water and apply with a hose so that the quantity can be controlled with exactness. When fresh burned lime is perfectly slaked, each 56 pounds of pure lime becomes 74 pounds of hydrated lime, water furnishing the added weight.

Hydrated Lime on the Market. A popular form of lime on the market is the hydrate. Manufacturers first burn the stone, and in the case of a pure limestone they drive off 44 pounds of each roo pounds 
of the weight in burning. Then, they combine enough water with the lime to change it to hydrate form, and that adds 18 pounds weight. It is run through a sieve to remove any coarse material, and then packed in bags which help to exclude the air. The small packages in which it comes upon the market make handling easy, and this helps to bring it into demand. Its good physical condition makes even distribution possible, and thus permits maximum effectiveness to be obtained. It is only slaked lime, identical in composition and value with lime of the same purity slaked on the farm, but some dealers have been able to create the impression that it has some added quality and peculiar power. This does no credit to the public intelligence, but the hunger of soils for lime is so great that investment at a price wholly out of proportion to the price of farm-slaked lime has rarely failed to yield some profit.

Degree of Purity. It is always a reasonable assumption that hydrated lime has been made from stone of a good degree of purity. 'A local stone, burned on the farm, may be of low grade, but no man of business judgment would erect a costly plant for 
burning and hydrating lime where the purity of the stone would not afford a good advertisement in itself.

On the other hand, we find very little hydrated lime on the market that has not had sufficient exposure to the air to become changed in some part to an air-slaked condition, or has had refuse mixed with it. 'Air-slaked lime is not worth as much per ton as the hydrate because it cannot correct as much soil acidity, and the percentage of the former cannot be determined by the buyer. Its presence may not be due to any wrong-doing of the manufacturer, and, on the other hand, the increase in weight that attends air-slaking may be welcomed in some degree by a dishonest manufacturer before the goods are shipped. The difficulty in preventing hydrated lime from adding to its weight by becoming air-slaked is a point to be taken into consideration.

The percentages of air-slaked material in hydrated limes are widely variable, and no manufacturer can standardize his product on the market surely for the benefit of the farmer. In some instances the product is adulterated with refuse material in finely pulverized condition. 


\section{CHAPTER XIII \\ OTHER FORMS OF LIME}

Air-Slaked Lime. A pure limestone is a carbonate, and the chemical formula is $\mathrm{CaCO}_{3}$. When it is burned, the carbon dioxide $\left(\mathrm{CO}_{2}\right)$ is driven off, leaving $\mathrm{CaO}$, which is calcium oxide, called fresh burned lime. In this process 44 pounds of a stone weighing roo pounds passes into the air, and there remain 56 pounds of lime. When it air-slakes, it takes back the carbon dioxide from the air, and the new product becomes $\mathrm{CaCO}_{3}$, or carbonate of lime, and regains its original weight of roo pounds. This is what would happen if the process were complete, and it is nearly so when the exposure to the air is as perfect as possible.

Fifty-six pounds of valuable material are in the roo pounds of air-slaked lime, just as is the case with limestone, and there is no difference in effectiveness except in so far as the air-slaked material is absolutely fine and available, while most pulverized limestone is less so. In making purchase for use of land the buyer cannot afford to make any 
appreciable difference in price in favor of air-slaked lime, as compared with a fine stone.

Air-Slaking a Slow Process. Lime changes to an air-slaked condition slowly unless it has full exposure. Old heaps will remain in hydrate form for many years, excepting the outside coat, which excludes the air. Complete air-slaking would not reduce ability to correct soil acidity, the total amount of calcium and magnesium remaining constant, but weight would be added in the slaking, and therefore the value per ton would be reduced. The slowness with which air-slaking proceeds gives reason to expect that any bulk of old lime may contain a considerable percentage of the hydrate, and therefore have greater strength than a true carbonate like limestone. This is a consideration of value to a buyer.

Agricultural Lime. Some manufacturers have found in the demand for lime by farmers an opportunity of disposing of much material that would not be satisfactory to manufacturers and builders. In some cases this so-called agricultural lime is sold at a price that is not beyond value, but it varies much in its content of pure 
lime. If the unburned cores of kilns are ground up, the material simply retains the value of unburned stone. Any air-slaked material put into it has like value. Forkings, ground up, have less value, and sometimes no value at all. Some better material may go into this mixture that is given the name "agricultural lime," and the product cannot be standardized or have a valuation given it that would be true for another lot.

Some manufacturers are marketing limes of fair values under this designation, but the values change as the material changes. There are other manufacturers who are putting poor stuff on the market. Unless one knows the manufacturer and his processes, he should not pay a great deal for "agricultural lime." It is much better to buy a high-grade lime or limestone that is more nearly constant in composition. When the word "agricultural" is part of the brand, there is assurance that the percentage of waste stuff in it is relatively high. Unless one knows to the contrary, he should assume that a ton of finely pulverized limestone is worth more per ton than "agricultural lime."

Marl. Marls vary in composition, as 
limestones do, but there are beds of chalky marl that contain very little clay and sand and are nearly a pure carbonate. It is only marls of high degree of purity that can be put on the market with profit, but beds of less pure marl furnish dressings for farms of the locality in many sections of the country. Some of these inferior marls have had so much clay and sand mixed with the lime carbonate that dressings must be heavy. The best lime marls provide excellent material for the correction of soil acidity, the actual value per ton being practically the same as that of the finest pulverized limestone. Some dealers in marl make extravagant claims for their goods, but any farmer may easily put these claims to the test and learn that he should not expect more than a fairly good carbonate of lime can do.

Marl improves the physical condition of stiff soils only when used in large amount per acre, and this is true of any carbonate form, such as limestone. Little effect upon physical condition should be expected from the light application usually given when marl is purchased and transported some distance to the farm. The chalk marl on 
the market is used to correct soil acidity, and at the best it is worth only what good lime carbonate is worth. It has no hidden virtues, and cannot take the place of fertilizers. It is an excellent means of meeting the lime-requirement of land when bought right, and its fine division makes it distinctly superior to coarse stone.

There should be no confusion of a lime marl with the so-called "green sand" marl. The latter is low in lime, and may be acid, the value of the marl being in a considerable percentage of plant food contained.

Oyster Shell. Ground oyster shell is a good source of carbonate of lime. The percentage falls below that of limestone, but in addition there is a little nitrogen and phosphoric acid. An analysis of a good quality of oyster shell, as found on the market', will show $90 \%$ carbonate of lime.

Burned oyster shell has something near the same composition as lime made from stone, but it goes back to hydrate and airslaked forms rapidly. There is no large amount of burned shell lime on the market, the material known as shell lime being the ground shell, or lime carbonate.

Wood Ashes. A large supply of lime in 
excellent form was afforded by hardwood ashes, but this product has ceased to have any important value to our agriculture. The chief supply on the market is low in quality, containing moisture and dirt in considerable amount, the form of lime being changed from an oxide to the hydrate and carbonate.

Gas Lime. Prof. E. B. Voorhees, in "First Principles of Agriculture," says: "Gas lime is also frequently used as manure; in gas works, quicklime is used for removing the impurities from the gas. Gas lime, therefore, varies considerably in composition, and consists really of a mixture of slaked lime, or calcium hydrate, and carbonate of lime, together with sulfites and sulfides of lime. These last are injurious to young plant life, and gas lime should be applied long before the crop is planted, or at least exposed to the air some time before its application. The action of air converts the poisonous substances in it into noninjurious products. Gas lime contains on an average $40 \%$ of calcium oxide, and usually a small percentage of nitrogen."

Lime After Magnesium Removal. A by-product in the removal of magnesium 


\section{OTHER FORMS OF LIME}

from a magnesian limestone is an excellent material for correction of soil acidity, on account of its physical condition. Its exposure to the air causes much of the hydrate to change to an air-slaked form, and its value per ton lies somewhere between that of very finely pulverized limestone and hydrated lime. 


\section{CHAPTER XIV \\ MAGNESIAN LIME}

Magnesium. As an element of plant food, magnesium is as essential as calcium. It leaches out of the soil less readily, and there may be even less need of its application as a plant food, though the need of calcium applications for this purpose is assumed to be small. In the correction of soil acidity magnesium is more effective than calcium, 84 pounds of the carbonate being equal to roo pounds of calcium carbonate. It is a curious fact, however, that there is widespread fear of magnesium as a soil amendment. This is not traceable to any considerable experience by practical farmers that inspires caution in its use, although immense quantities of magnesian limestone and lime have been used. Neither is it due to any weight of evidence against it in the experience or teachings of soil chemists and experiments. The facts of the case appear to be as follows:

I. An investigator found in his laboratory that a plant growing in a water solution 
was injured when magnesium was added, and that the injury was checked when calcium in equal amount was added to the water. The theory was worked out that a soil should not contain a greater total amount of magnesium than of calcium, and as the soil's supply of calcium tends to leach out more readily than the supply of magnesium, it was best to use a high-calcium lime. If this discovery of the laboratory had been carried into the field, its significance would have dwindled to zero in the case of normal soils, and a lot of exploitation would have been rendered impossible. As it was, the discussion went merrily along until it occurred to some one to test the matter in the soils where plants grow, and one would now hear little of it if commercial interests were not at stake.

2. Very much of our limestone supply is high in magnesium, and some men who have limestone very low in magnesium and high in calcium have done a good stroke of business for themselves by deepening the public's impression, due to laboratory tests with water cultures, that magnesium in lime is injurious.

3. Many people knew "lime," but had no 
knowledge of magnesia, and if it was an impurity like clay or sand, cutting down value per ton, and if it was worse because harmful, they wanted none of it.

The Fact's Importance. If every farm could get its supply of pure calcium lime as cheaply as it can have magnesian lime, the truth respecting the value of the latter would have small agricultural importance, but as a great bulk of farm and commercial supplies of lime is magnesian, financial injury has been done consumers who have paid more than should have been paid for relatively pure calcium lime and limestone, being afraid to use goods whose content of magnesium was not small. It is poor policy to use either kind of burned lime in great excess, but when rationally used on all soils except sandy ones, there is no preference to be exercised that can be based upon performance. 'A magnesian lime corrects as much acidity as a high calcium lime, and a little more, and its use is to be recommended if there is any advantage in the matter of price, except in the case of distinctly sandy soils.

Magnesian Limestone. Leading scientists making tests of limestone for normal 
soils, use magnesian limestone freely. They recommend its use to farmers wherever there is advantage in point of price. The advice is safe that the limestone of a given fineness should be chosen whose total percentage of carbonates of calcium and magnesium is the highest. The example of these scientists, buying pulverized limestone for agricultural colleges and experiment farms, and for their own farms, should loosen the curious hold that the early warnings of a laboratory experimenter took upon public imagination. The farmer should buy limestone on a basis of ability to correct soil acidity, and make each dollar do the most possible toward that end.

Most limestones contain some percentage of magnesium, and in the case of a pure dolomite over $45 \%$ carbonate is present in combination with calcium carbonate. A stone rich in magnesium slakes less readily than one high in calcium, and therefore is preferred by manufacturers shipping pulverized burnt lime to reach its destination before slaking. 


\section{CHAPTER XV}

\section{WHAT SHALL ONE BUY?}

Relative Values. The relative strengths of the various materials containing lime may be known and yet doubt continue respecting the choice to be made. The conflicting claims of dealers, and inaccurate deductions from a single test made by some individual, aid the confusion. If there were always the single purpose of correcting soil acidity, and if there were the same ease of application in case of all the materials, the choice would present much less difficulty. Notwithstanding this, most land now has a lime requirement, or will have one as leaching, crop removal and chemical change within the soil continue, and the puzzle is no worse than a score of others that present themselves continuously in farming.

Destroying Acids. The cost of liming to improve the physical condition of land is prohibitive for most farms remote from supplies of stone that can be burned and put upon the land at a low price per ton. Where stone is at hand, and soils are in- 
tractable, lime burned on the farm should be used. Some slight benefit to a stiff soil may be obtained from the light application that is deemed practicable where all forms are costly, but this benefit is not usually marked in case of an application of a ton or less of burned lime. It is a safe statement that most buyers of lime in some form or other will profit chiefly through the correction of soil acidity and promotion of bacterial life. This renders the situation more simple as any carbonate, hydrate or oxide of lime will accomplish these purposes.

Composition. The first consideration is the actual content of calcium and magnesium. A guaranteed analysis is the only safe basis of purchase. The unstable nature of fresh burned and hydrated forms makes an exact statement of percentages impossible for goods not wholly fresh, but at least the purity of the original limestone can be judged.

Equivalents. One ton of fresh burned lime, made from pure stone, is equivalent to 2640 pounds of the hydrate, and to 3570 pounds of pulverized limestone or of airslaked lime. It is easy to carry in mind the proportions expressed by $I, I \frac{1}{3}$ and $I \frac{3}{4}$. 
If there were no other considerations, such as convenience in han ing, evenness of distribution, etc., to take mito account, one ton of fresh burned lime, one and a third tons hydrated and one and three-quarters tons finely pulverized limestone would have the same value when delivered in the field. Lime fully air-slaked, high-grade marl, and finely pulverized limestone would have the same value, ton for ton.

Even Distribution. The value of even distribution is not easily overestimated. If lime in proper amount does not go into each square foot of an acid soil, some of the soil will remain sour unless mixing is done by implements of tillage. Lime is diffused laterally through the soil in a very slight degree. If a strip of sour land is protected by canvas, so that no dust from lime applied to uncovered land can blow upon it, a seeding to clover will show that plants a few inches from the edge of the limed area will fail to start thriftily and may die before their roots reach the lime. Full effectiveness of an application is possible only through even distribution.

Using Lump Lime. Lump lime, slaked on the farm, is difficult to apply satisfac- 
torily. Spreading with a shovel from small heaps is bad practice, and when the lime is slaked in a large heap, it cannot be handled as well as pulverized stone or commercial hydrated lime. The latter two are in condition for application by means of a lime distributor, or even a fertilizer attachment of a grain drill. The farm-slaked lime contains impurities that interfere with distribution.

An Estimate. It is always hazardous to attempt an estimate of cost of labor without knowing the particular farm conditions, but the expense and discomfort attending the slaking and use of lime bought in lump state justify a willingness to pay as much for a ton of hydrated lime as lump lime would cost, although the former has only threefourths as much strength as the latter. Some farmers pay nearly twice as much for the hydrated, partly to escape the inconvenience and partly because they hope that the extraordinary claims for superiority made by some dealers may prove true. They should know that it is only fresh burned lime slaked, but incline to credit a claim that special treatment enhances value in some mysterious way. 
Comparing lump lime with finely pulverized limestone, the factors of expense and discomfort and final lack of perfect distribution of the former remain important. The stone is relatively easy to handle, being slightly granular and passing through a distributor without trouble. The fact that it is not caustic, like the hydrated, is in its favor. When everything is taken into account, one is justified in using limestone or air-slaked lime at a cost per ton threefourths as great as that of lump lime. It is to be borne in mind that in these estimates the cost per ton is not that at the factory or at one's own railway station, but on the farm. The freight and cartage to the farm are based on weight of material, and more material per acre is required when the worthless portion has not been driven off by burning. If one must use one and threequarters tons of limestone to have the equivalent of one ton of fresh burned lime, it is evident that the cost of freight and cartage of the worthless portion might make cost prohibitive if distances were very great. Farms lying a long distance from a railway station may easily find that fresh burned lime is the only form of lime they 


\section{WHAT SHALL ONE BUY?}

can afford. The basis for correct estimate is cost delivered in the field.

Storage. One advantage possessed by the limestone is ease of storage. There is no inconvenience or loss. The stone may be ordered at any time of the year when teams are least busy upon other work, and it can be held till wanted. In this way the cost of cartage to the farm may be kept relatively low, and the material is at hand when wanted, regardless of rush of work or delays of railroads. This advantage is partial counterbalance to the cost of freight on the worthless portion of unburned stone.

Valuing Limestone. The estimates, so far as labor and convenience are concerned, are merely suggestive, and rest upon the presumption that the stone is satisfactorily fine. It has been urged in another chapter that immediate effectiveness is determined by fineness, but as a working basis we assumed that when all the stone would pass through a screen having sixty wires to the inch it would give the desired results. The coarsest portion would not be available at once, but when an application is heavy enough to serve for a year or more, we have enough very fine material in such a grade of 
stone to meet immediate need. When estimating values of such a grade and coarser grades, the amount per acre to be used is a factor. The coarse is unsatisfactory if the price is not low enough to permit an application sufficient for a considerable term of years, so that it will contain all the fine material needed at once. In that case the coarser material may be expected to meet later need, and may be even more desirable for such purpose, as it would not be subject to leaching.

Coarse grinding costs much less than fine grinding, and it is the resulting low price that permits the heavy application. As stone varies in hardness and ability of the small particles to withstand disintegrating forces in the soil, an estimate of the difference in price between a 60-mesh limestone and a ro-mesh one could not serve as a safe guide. The buyer should know the percentages of a limestone passing through screens of various sizes before he makes a purchase, and should demand part of the saving in cost of production that attends coarse grinding.

Oyster Shell. Ground oyster shell should be given about the same valuation as 


\section{WHAT SHALL ONE BUY?}

limestone. It is a lime carbonate, and the percentage of worthless material in it varies somewhat. It is coarsely ground, but the large pieces disintegrate in the soil much more rapidly than limestone would do. It contains a little nitrogen and phosphoric acid, partially available, as an offset to coarseness and some lack of purity, as compared with the highest grade of fine stone. It is profitable to buy oyster shell at limestone prices if used liberally enough to furnish a supply for a term of years. The oxide, or burned shell lime, would be nearly the equivalent of burned stone if it did not change to hydrate and air-slaked forms so rapidly that it rarely is on the market in the full strength of fresh burned lime.

Hardwood Ashes. As a source of lime, ashes have become far too expensive. The composition of ashes on the market is widely variable, dirt and moisture often accounting for much of the weight. The lime in fresh burned ashes is peculiarly effective, being finely divided and in oxide form, but the ashes on the market have much of the lime water-slaked and air-slaked. Unless analysis is made at time of purchase, a buyer should not estimate the content of lime in a 
ton at a value greater than assigned to onehalf of a ton of limestone. The additional value of the ashes, due to the potash content, is wholly another consideration.

Marl. No more should be paid for a ton of good chalk marl than an equal weight of fine limestone would cost. Each is a good carbonate of lime, with the same capacity for destruction of acids.

Agricultural Lime. This variable product should not be bought unless actual composition is known, or the cost is as low as that of pulverized limestone, and even then it may be a bad purchase, the methods of the manufacturer being the determining factor. If such lime is chiefly a dumping place for low-grade stone and forkings, it has small agricultural value.

Land Plaster. The soil wants lime in carbonate form. The oxide and hydrate change to carbonate, and therefore are good. Land plaster is a sulphate, and its tendency is to make a soil sour. It should not be considered as a means of correcting soil acidity.

Basic Slag. The amount of effective lime in basic slag, as made by modern methods, is so small that its value is nearly negligible. Basic slag is a good source of phos- 


\section{WHAT SHALL ONE BUY?}

phorus, and in addition has a tendency toward correction of soil acidity, but such tendency has little cash value for land that requires a considerable dressing of lime to furnish a base with which soil acids may combine.

An expression of opinion was obtained recently from some leading soil chemists of this country, and upon such expression we base the estimate that when pulverized limestone costs three dollars a ton, the value of the lime in a ton of basic slag should not be placed higher than 50 cents, and some chemists believe that the lime content is entirely negligible as an agent in soil amendment.

Lime in Other Fertilizers. The demand for lime is leading some men to state a lime content for their goods that is designed to mislead. Such lime is not in a form to combine with soil acids, and is as valueless as the very large amount of lime in acid soils that is in compounds having no power to affect free acids. 


\section{CHAPTER XVI}

\section{METHODS OF APPLICATION}

A Controlling Principle. The chief purpose of liming land is to provide a base with which acid may combine, so that the soil may be friendly to plant life. Lime has little power to distribute itself through a soil, and harmful acid may remain only a few inches distant from the point where lime has been placed. In a general way, the tendency of lime is downward, especially when the application at the surface is heavy. Economical use demands even distribution through the soil so that a sufficient amount is in every part. Means to that end are good means of distribution.

Spreading on Grass. Where lime is burned on the farm, and little account of labor is taken, it has been a common custom to spread the lime on grass sods the year previous to breaking the sod for corn, using I00 to 300 bushels per acre. Rains carried some of the lime through the soil, and the increased yields for a few years were due to the improved physical condition of a stiff 


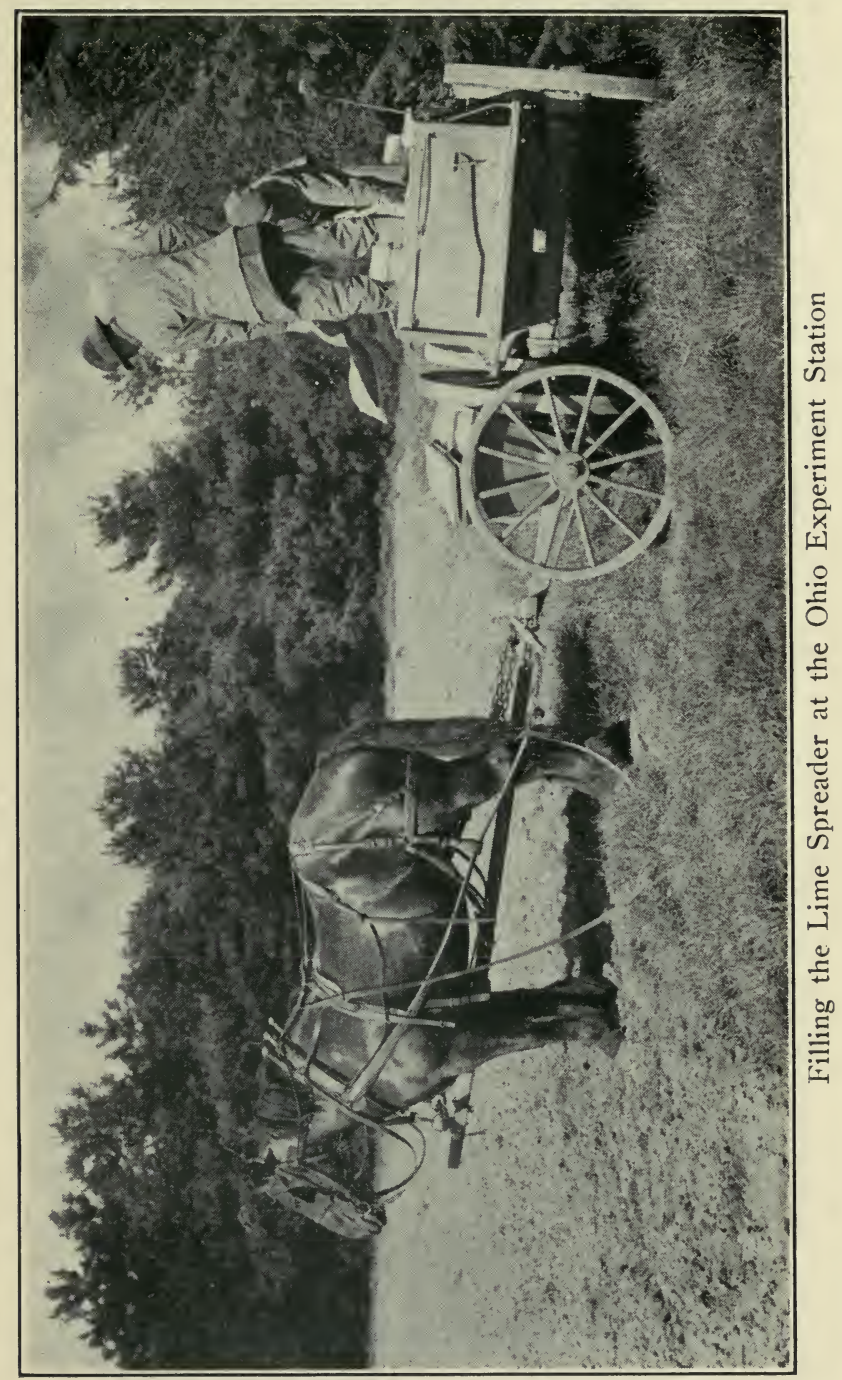




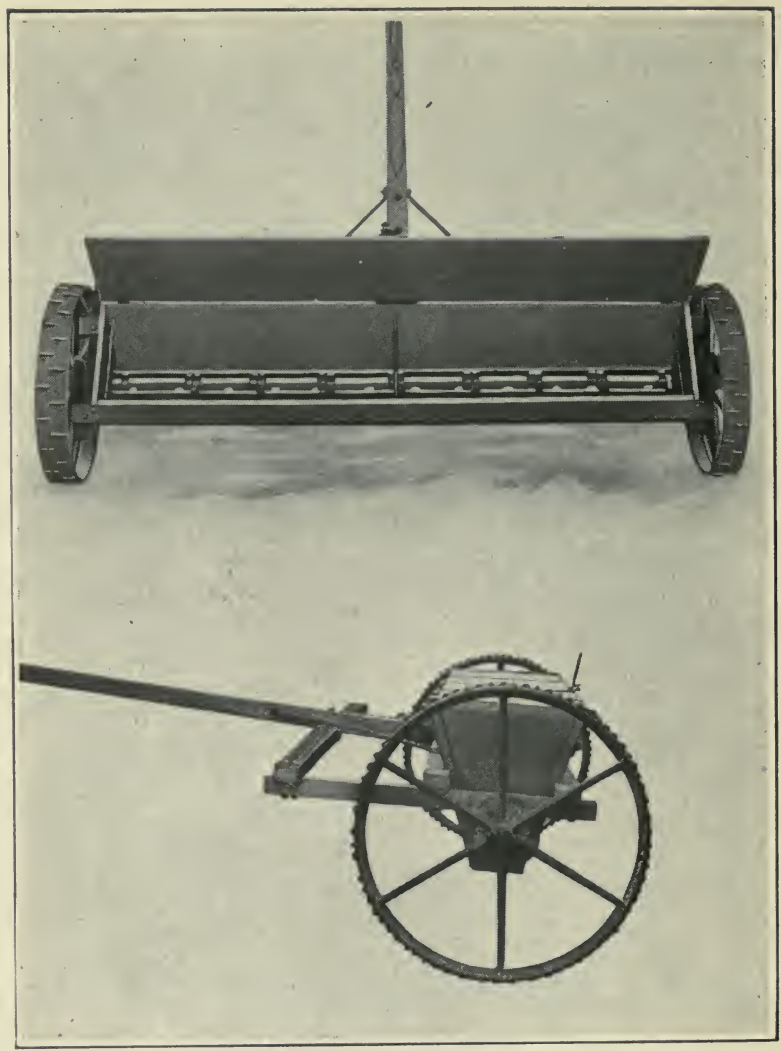

Lime Distributers 
soil that a heavy application of caustic lime produces, and to the disintegration of organic matter and to change in compounds of mineral plant food. The practice is rightly going into disrepute, being wasteful and harmful.

The smaller application of any form of lime to correct soil acidity may be made on grass land that should not be plowed, but the full effectiveness of an application is not secured in top-dressings. If the land is under a crop rotation, it is better practice not to apply the lime on grass, but to defer application until the sod has been broken, when the lime can be intimately mixed with the soil by use of harrows. It is the rule that it should go on plowed land, and should be mixed with the soil before rain puddles it. In no case should it be plowed down.

When clover or alfalfa shows a lime deficiency, it is advisable to make an application, either in the spring or after a cutting, obtaining whatever degree of effectiveness may be possible to this way, but the fact remains that full return from an application is secured only after intimate mixture with the soil particles. On the other hand, 
if land needs lime, and there is not time or labor for the application when the soil can be stirred, it is far better to apply on the surface during any idle time than to leave the soil deficient in lime.

Distributors. The most satisfactory means of distribution is a machine made for the purpose. A number of good distributors are on the market. They are designed to handle a large quantity of material after the fashion of a fertilizer distributor ordinarily attached to a grain drill. A V-shaped box, with openings at the bottom, and a device to regulate the quantity per acre, enables the workman to cover the surface of the ground with an even coat, and the mixing with the soil is done by harrows.

Light applications can be made with a drill having a fertilizer attachment. Some makes of drill have much more capacity than others. Granular lime, such as limestone, is handled more satisfactorily than a floury slaked lime.

Farm-Slaked Lime. Lime slaked on the farm must continue to be a leading source of supply to land. If there is stone on the farm, and labor in the winter is available, it 
is not a costly source of supply. The chief drawback to the use of farm-slaked lime is the difficulty in securing even distribution. The loss from spreading with shovels from small piles slaked in the field is heavy. The quantity per acre must be large to insure sufficient material for every square foot of surface. The lime slaked in a large heap can be put through distributors only after screening to remove pieces of stone, unless they are made with a screening device, and the caustic character and floury condition make handling disagreeable, but no other method is as economical when lime is high in price.

Use of the Manure Spreader. The next best device is the manure spreader. The makes on the market vary in ability to do satisfactory work with lime, and none does even work with a small quantity per acre. An addition to the bulk to be handled by placing a layer of other material in the spreader before filling with lime helps, but some spreaders do fair work in spreading as little as 3000 pounds of slaked lime per acre, and certainly far better work than usually is done with shovels from a wagon. 


\section{CHAPTER XVII}

\section{AMOUNT OF LIME PER ACRE}

Soils Vary in Requirement. There is always the insistent question respecting the amount of lime that should be used on a particular field. Usually no definite reply can be safely made. The requirement of the present, and probably of the next few years, should be met by one application. The existing degree of acidity is an unknown quantity until a careful test has been made. There are soils so sour that several tons of fresh burned lime per acre would only meet present requirement, and there are soils so soundly alkaline that they need none at all. This uncertainty regarding amount required is responsible for much failure to do anything, even when some acidity is indicated by general appearance.

$A$ Working Basis. If land has once been productive and in later years clover has ceased to grow and grass sods are thin, there is a strong probability that liming will pay, and the experience of farmers on normal soils, and the tests of experiment 
stations, justify the estimate that two tons of fine stone, or one and a quarter tons of fresh burned lime per acre, can be used with profit. This amount probably will permit fertilizers and tillage to make their full return in heavy sods that will provide humus. It is a reasonable expectation that the application will serve through a crop rotation of four or five years.

If the soil was not very sour, the second application at the end of four or five years may be reduced somewhat, and even a ton of stone given once in the crop rotation may fully meet the requirement.

In the case of the normal soil that has ceased to grow clover, and does grow plants that are acid-resistant, it is better practice to secure a relatively low-priced supply of coarsely pulverized stone and apply three or four tons per acre, and thus lengthen the interval between applications to eight or ro years. The fine material in the heavy application will take care of present need, and the coarser particles will disintegrate later on.

The quantities suggested may not be the most economical for the reader, but their use cannot be attended by loss if a soil is 
sour, and there is reason to believe that it is much better to use such quantities without question than to defer liming for a year in the hope that some more definite knowledge of a particular field's needs may be secured.

Small Amounts Per Acre. There is much experience as a basis for the claim that a few hundred pounds of burned lime per acre may have marked results. Fields that indicated an actual lime requirement of a ton of fresh lime per acre have had a test of 500 pounds per acre made in strips, and the clover later on was so superior to that which was struggling to live in the untreated portion that the light application appeared almost to be adequate. In such land there cannot be full bacterial activity or continuing friendliness to plants unless the need is met fully. A larger application would have paid better. It is the soil rich in lime that can make the best response to tillage and fertilization.

A Heavy Soil. When burned lime is not high in price, an application of two tons per acre may be more profitable than a smaller one. 'A heavy soil needs to be richer in lime than a light one for best re- 
sults, and physical condition also is improved by the larger quantity. A correspondingly heavy coat of stone will give quite satisfactory results, but effect upon the texture of the soil is less marked.

Sandy Soils. It is inadvisable to apply any large quantity of caustic lime to a light soil. Such a soil does not need as high a percentage in it as a heavy soil requires for good results, and caustic lime can easily injure physical condition. Limestone is safe for use, and is to be advised for all quite sandy land. Acidity rarely runs high in a light soil, and the opinion is hazarded here that one ton of stone per acre meets the needs of a light soil about as surely as two tons supply a heavy soil. In case of each type of soil there are wide exceptions, and yet these estimates form a basis for the judgment of the individual farmer. 


\section{CHAPTER VIII SPECIAL CROP DEMANDS}

Lime-Loving Crops. There are plants which are acid-resistant, giving a good return for fertilization and care when the soil is sour. There are a few kinds of cultivated plants that seem to prefer an acid soil, and to resent lime applications. Most staple crops prefer an alkaline soil, or at least one that has no large requirement, and there are plants that thrive best only in land rich in lime. Not all such plants require more as a component part of their structure, but do have a high percentage in their ash.

Liming for Alfalfa. When all other conditions are right, alfalfa thrives or fails according as a soil is rich in lime or is distinctly deficient. It is entirely possible to get fair yields of this legume for a short time from land that is not fully alkaline, but full yields and ability to last for a term of years depend upon a liberal lime supply. Alfalfa is at home only in a naturally calcareous soil, or one that has been given some of the characteristics of such land by 


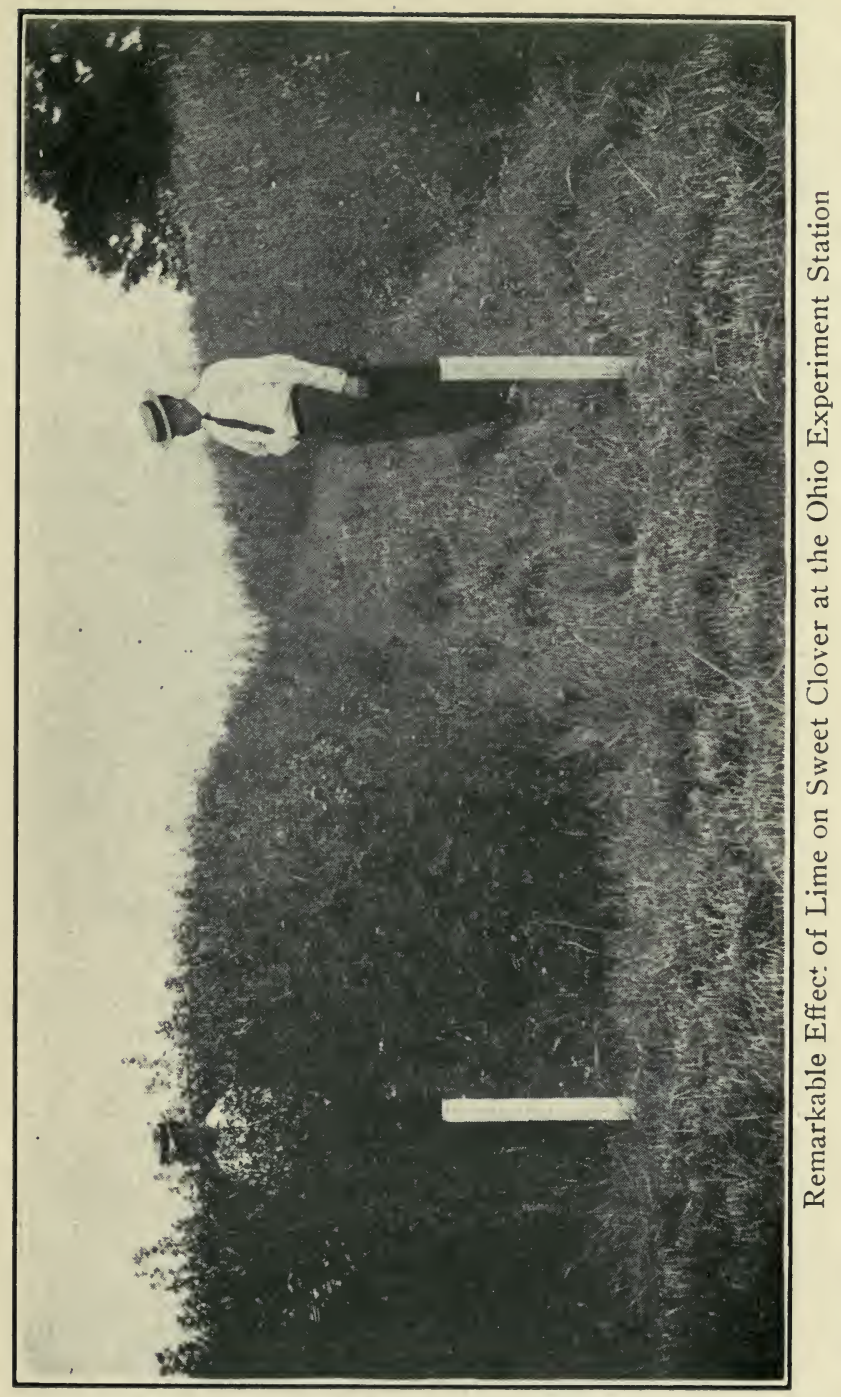




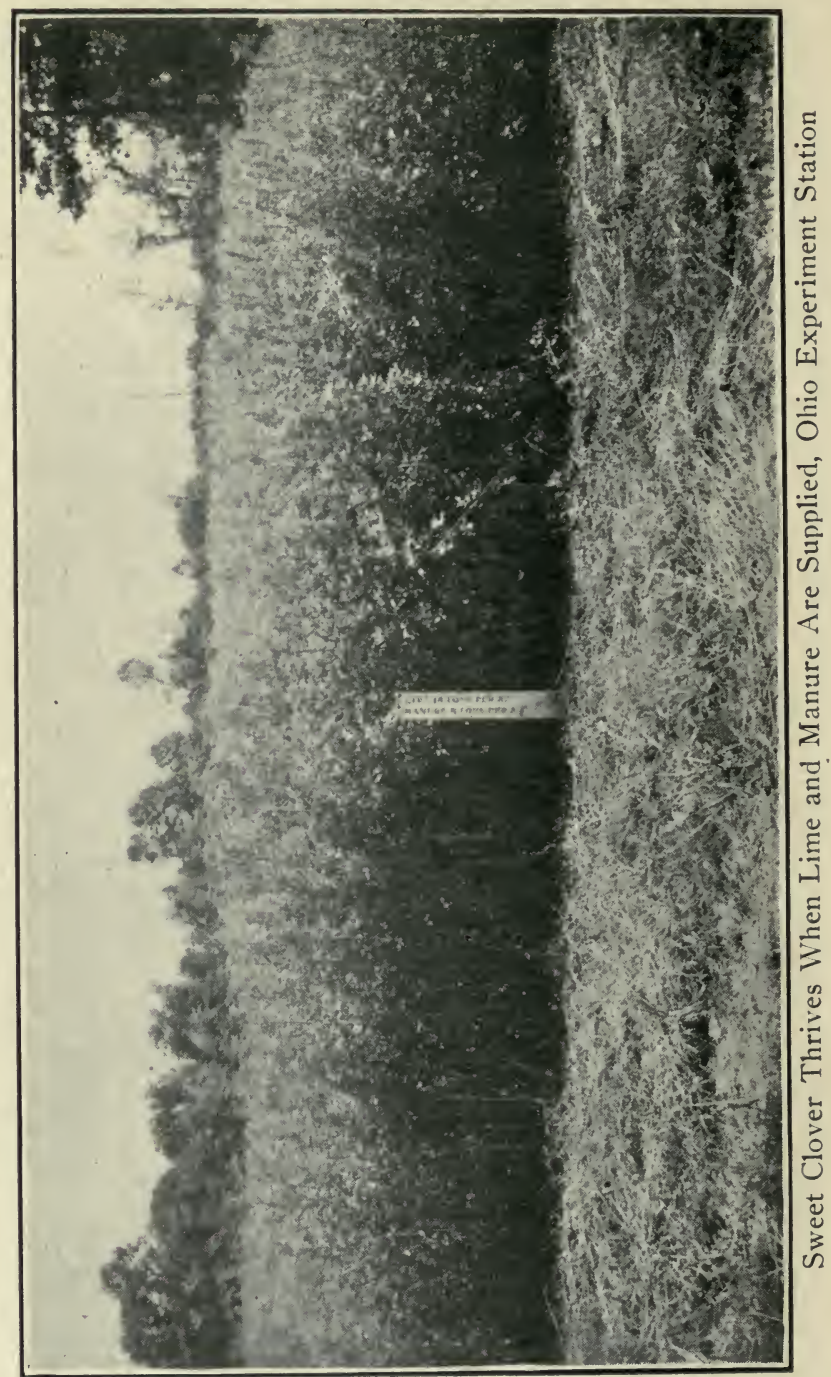


free use of lime. In the case of neutral or slightly acid ground it is good practice to mix four tons of limestone per acre thoroughly with the soil. Such treatment gives greater permanence to the seeding, enabling the plants to compete successfully with the wild grasses and other weeds that are the chief obstacle to success in the humid climate of our Mississippi valley and eastern states. When this amount of stone is used, the finest grade may not be preferred to material having a considerable percentage of slightly coarser grains.

Red Clover. When land is in excellent tilth, it may grow red clover satisfactorily while showing a decided lime deficiency. On the other hand, much slightly acid land fails to grow clover, and an application of lime is followed by heavy growths. Red clover is most at home in calcareous soils, and lack of lime is a leading cause of clover failure in this country. Other causes may be important ones in the absence of lime and be overcome when it is present.

Alsike Clover. Most legumes like lime, and alsike clover is not an exception, but is far more acid-resistant than the red. It is less valuable, both for soil improvement 
and for forage, having an inferior root system, but has proved a boon to farmers in areas that have been losing the power to grow red clover. The custom of mixing red and alsike seed has become widespread, and distinctly acid soils are marked in the clover flowering season by the profusion of the distinctive alsike bloom to the exclusion of the red. While there is acid-resistant power, this clover responds to liming.

Crimson Glover. Among lime-loving plants crimson clover has a rightful place, but it makes fairly good growth where the lack of lime is marked.

Bluegrass. The heaviest bluegrass sods are found where lime is abundant in the soil. This most valuable pasture grass may withstand the encroachments of weeds for a long time when lime is not abundant, if plant food is not in scant supply, but dependable sods of this grass are made only in an alkaline soil. Heavy liming of an acid soil pays when a seeciing to permanent pasture is made, and old sods on land unfit for tillage may be given a new life by a dressing.

Crops Favored by Lime. Nearly all staple farm crops respond to applications 


\section{SPECIAL CROP DEMANDS}

given acid soils. Corn, oats, timothy, potatoes and many other crops have considerable power of resistance to acids, but give increased yields when lime is present. Liming is not recommended for potatoes because it furnishes conditions favorable to a disease which attacks this crop. When clover is wanted in a crop rotation with potatoes, it is advisable to apply the lime immediately after the potato crop has been grown, and to use limestone rather than burned lime. Most kinds of vegetables thrive best in an alkaline soil. 


\section{INDEX}

Air-slaked lime, composition and relative value of.......31,

Agricultural lime, composition and relative value of. ...58,

Amount of lime per acre.....

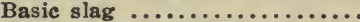

Burning lime, methods of......

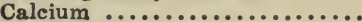

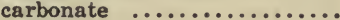

hydroxide...$\ldots \ldots \ldots \ldots \ldots$

oxide .....................

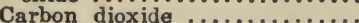

Causes of soil acidity $.10,12,13$,

Caustic lime affects physica condition ..............44, acts on humus ..........44, frees inert plant food....... compared with limestone ... irrational use of............. may injure a sandy soil..66, right use of................

Caustic magnesian lime on

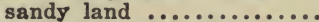

Chemical changes produce acid-

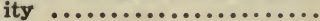

Clover .............17, 19,

Compositon of limestone, $24,30,31$,

Distribution of lime........70,

Distributors .............80,

Dolomite ......................

Equivalents in value..........

Extent of soil acidity......6,

Fineness of limestone.......39,

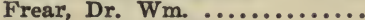

Fresh burned lime................. composition and relative value of $\ldots \ldots \ldots \ldots 29,31,45,69$,

Gas lime $\ldots \ldots \ldots \ldots \ldots \ldots \ldots$

Ground limestone, composition and relative value of $30,33,69$

Hydrated lime, composition and relative value of $30,31,53$,

Indications of soil acidity

$$
5,15,17 \text {, }
$$

Irrational use of lime........9,

Land plaster .................

Leaching ..............12,

Lime for alfalfa.............

alsike clover .............

bluegrass ................

erimson clover ............

potatoes ..................

red clover ................

most staple crops ..........

in fertilizers . . . . . . . . . . .

is unstable ............... mecessary centent variable .. on sandy soils .............
Page

76

82

76

49

29

30

30

29

30

14

46

47

44

45

44

85

48

66

13

87
Limestone burned to effect distribution .............. 34

land, value of $\ldots \ldots \ldots \ldots .4,6$

varies in composition ..... 33

Litmus paper test............ 20

Low-priced pulverizers ....... 35

Lump lime and hydrate compared ................. limestone compared .........

Magnesian lime ............. 64

limestone ............... 66

Magnesium ....................... 64

Marl, composition and relative value of ............59,

New York experiment station..

Old heaps of burned lime......

Oyster shells, composition and relative value of........61,

Redtop ...................

Relative values of lime..68, $7 \dot{1}$,

Removal of lime in crops......

Slaking lime ...............

Small applications may pay...

Soil acidity, cause of $10,12,13$, extent of $\ldots \ldots \ldots \ldots \ldots \ldots \ldots$, indications of $\ldots \ldots . . . .15,17$, tests for ............... Soils vary in lime requirement Sorrel and plantain .......... Spreading farm-burned lime 70 , Storing lime in the soil.......

Storing limestone ........... Source of lime, as :

agricultural lime .......58, air-slaked lime ............31, fresh-burned lime ....29, 31, gas lime ................

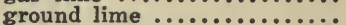
ground limestone .........30, hydrated or slaked lime...31, magnesian limestone ......... $\operatorname{marl} \ldots \ldots \ldots \ldots \ldots \ldots \ldots \ldots \ldots$ oyster shells ..........61, wood ashes ..............61,

Source of lime in soils.......

Technical terms ............. Tests for soil acidity.............

Thin soils usually acid.........

Timber as an index ......... Timothy ................

Truog, Prof. \$. .............

Truog test ..................

Value of lime after magnesium remov 1 .............

Voorhees, Dr. E. B. ..........

Warding off soil acidity ......

When production decreases ....

Wood ashes, composition and relative value of $\ldots .25,61$,
76

42

58

75

18

72

14

53

84

14

11

18

21

82 




\section{4}

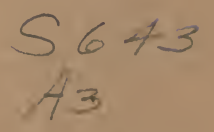

UNIVERSITY OF CALIFORNIA LIBRARY 
